\title{
Afghanistan Land Ownership
}

Submitted to the Office of the A.I.D. Representative for Afghan Affairs

\section{Under}

Contract No. 306-0205-C-00-9385-00 Delivery Order No. 13

\section{August 1991}

Submitted by

Nathan Associates Inc. and Louis Berger International, Inc. A Joint Venture

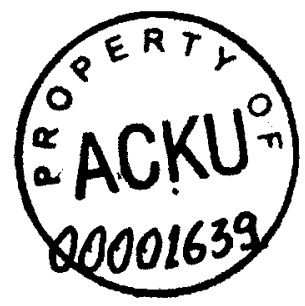




\section{CONTENTS}

Chapter

Page

EXECUTIVE SUMMARY

1. INTRODUCTION 11

Objectives

General Context

2. CHARACTERISTICS OF LAND OWNERSHIP IN AFGHANISTAN 15

Classifications of Land by Productive Use 15

Principal Forms of Land Tenure 22

Techniques for the Use of Land as Security for Debt 25

Means of Adjudicating and Enforcing Rights to Land 28

Existing Formal Systems Pertaining to Land Tenure 29

1978 Land Reform 33

Geographic Distribution of Particular Types of Ownership 34

3. LAW AND CUSTOMARY REGULATIONS ON STATE-OWNED,

COMMUNAL, AND COMMON LANDS 39

Historical Background $\quad 39$

Adequacy of Environmental Protection on Public and
Common Lands

4. LAND TENURE PROBLEMS ANTICIPATED WITH THE

RETURN OF REFUGEES $\quad 43$

Major Resettlement Issues 43

Implications for Returning Refugees 46

Issues and Principles To Address Confiscated Lands Issues 48

Relationship Between Land and Water Rights 49

5. OPPORTUNITIES FOR USAID 51

REFERENCES

$\begin{array}{ll}\text { BIBLIOGRAPHY } & 57\end{array}$ 


\section{CONTENTS}

(continued)

\section{LIST OF TABLES}

$\underline{\text { Page }}$

Table 1. Shift in Use of Land Resources, 1978-1979 to 1989-1990

16

Table 2. Distribution of Land Use and Cropping, 1978-1979 to 1989-1990

Table 3. Estimated Distribution of Agricultural Land by Form of Tenure

Table 4. Land Tenure Survey Responses by Region

Table 5. Average Annual Per Capita Income and Land Availability of Selected Provinces, 1970

Table 6. Agricultural Population and Land Ownership of Selected Provinces, 1977-1978

\section{LIST OF MAPS}

Map 1. Regions of Afghanistan

Map 2. Cropping Patterns

Map 3. Forests

Map 4. Regional Changes in Land Ownership, 1978-1979 to 1987-1988 (from Table 4)

Map 5. Approximate Sites of Government Irrigation Projects 


\section{EXECUTIVE SUMMARY}

Afghanistan is primarily an agricultural country. Land ownersinip is part of a seamless web that includes local politics, land titles, water use, and social hierarchy, all of which heavily affect the use of the land. in an agrarian society such as Afghanistan's these phenomena cannot be separated from the economic life of the country. Any change in land tenure implies a change in the structure of social power and is likely to affect the use of the land.

The land tenure system reflects the evolution of an economy and its needs. As time passes and society progresses, according to Feder and Feeney (1991),

Increasing population density, appreciation in the agricultural terms of trade, and technoiogical change, which made investments in land quality more profitable, have enhanced the benefits from creating more precise private property rights in land. The demand for institutional arrangements to describe and enforce property rights in land with more precision is thus a common feature in many developing countries.

Such precision is demanded as a way to increase incentives for land investment and conservation, facilitate credit transactions, permit transfer of lands to those with higher productivity uses, and, not the least, minimize the turmoil that often surrounds the determination of land titles.

Afghanistan was moving toward greater precision in private property rights in land during the 1970 s only to have the process interrupted at an early stage by the coup and ensuing civil war and invasion from 1978 onward. These events have exacerbated the problems of land ownership determination by creating new claims and destroying former institutions for enforcing rights to land.

Afghanistan comprises an area of 65.3 million ha. of land, of which only 12 percent or nearly 8 million ha. is arable. Of the 8 million ha. of arable land, only 4 million ha., or $\mathbf{5 0}$ percent, is cultivated in a normal year. 
Before 1978, about 2.6 million ha. was reported to be irrigated; of this amount, about 1.4 million ha. received adequate water for double cropping, and another 13 million ha. was dry farmed. The following table gives Afghanistan land resources for 1978-1979 and 1989-1990. ${ }^{1}$ For cultivated land, approximately 26 percent of the irrigated land and 40 percent of the nonirrigated land are fallow.

1978-1979

Land Classification
Arable land
Cultivated
Irrigated
Wheat
Other cereals
Fruits and nuts
Industrial crops
Other
Nonirrigated
Wheat
Other
Total cultivated
Uncultivated
Total uncultivated

Forest

Pasture

Mountains and desert

Total land area

\begin{tabular}{rc}
\hline Area & Percent \\
7,910 & 12.0 \\
& \\
1,300 & 2.0 \\
834 & 1.3 \\
141 & 0.2 \\
134 & 0.2 \\
170 & 0.3 \\
& \\
1,048 & 1.6 \\
248 & 0.4 \\
3,873 & 6.0 \\
4,037 & 6.0 \\
4,037 & 6.0 \\
1,900 & 3.0 \\
40,000 & 61.0 \\
15,453 & 24.0 \\
65,263 & 100.0 \\
&
\end{tabular}

$1989-1990$

\begin{tabular}{rc}
\hline Area & Percent \\
7,910 & 12.0 \\
& \\
1,030 & 1.6 \\
742 & 1.1 \\
137 & 0.2 \\
67 & 0.1 \\
149 & 0.3 \\
715 & \\
216 & 1.1 \\
3,056 & 0.3 \\
4,854 & 4.7 \\
4,854 & 7.3 \\
1,900 & 7.3 \\
40,000 & 3.0 \\
15,453 & 61.0 \\
65,263 & 24.0 \\
& 100.0
\end{tabular}

Between 1978-1979 and 1987-1988, the total area of irrigated land declined by 21 percent, and the rainfed area declined by some 30 percent, as a result of abandonment, inadequacy of farm power, and destruction of irrigation facilities in rural areas. The largest decline in cultivated area (50 percent) is reported to have occurred in the southwest region encompassing Paktika, Helmand, Kandahar, Nimrorze, and Uruzgan provinces. In the southeast region, which encompases Paktia, Nangahar, Laghman, and Kunar provinces, the area cultivated declined by only 3 percent. Over the last 3 years, some of the abandoned land has been returned to cultivation, yet the total area cultivated in 1989-1990 was about 21 percent less than what it had been in 1978-1979.

'Sources: "Afghanistan: Opportunities for Agricultural and Rural Development, Sector Report", World Bank, 1975, page 8; "Afghanistan: Journey to Economic Development," Vol. II, Table 7.1; StatisticalYearbook, Central Statistics Organization, 1989, page 103. 
Although the cultivated area has declined by about 21 percent since 1978, the cropping pattern has remained almost unchanged. Cereal production accounts for 87 percent of cultivated land; wheat alone occupies 57 percent. About 42 million ha. is forests or pastures.

Most of Afghanistan's arable land is privately owned. Both sharia (Muslim religious law) and the constitution provide for extensive state land holdings. In theory, the state owns three categories of rural land: (1) Waqf Muslim religious trust land, which was nationalized in the 1890s by King Abdur Rahman; (2) the floodplain that borders the south shore of the Oxus (Amu Dharya) from Samangan upstream (government land in principle); (3) all wasteland, forests and pastures, which the government claims but has made little attempt to restrict or regulate.

According to sharia, lands neither privately owned nor cultivated belong to the state. In addition, the state had various claims to categories of arable land such as state farms and wastelands reclaimed by government irrigation projects. Arable public lands were frequently let on long-term lease for cash rent by the government, although no law exists that authorizes these leases. By contrast, private land is rarely leased for fixed rent. A portion of privately owned land-previously about one-third, now one-sixth-is sharecropped. A considerable portion of privately owned land is mortgaged, with payments that are quite similar in function to rent in that the land actually is transferred to the lender and the borrower pays the lender for its use. Other private lands are cultivated by laborers under the supervision of the landowner or by the owner himself.

Despite the state's claims, many of the state lands, especially forests and pastures were, in fact, communal lands, controlled and used according to long-accepted custom by one or another tribal group with rights to exclude. others.

Even in 1978 Afghan private landholdings were small and fragmented and unequally distributed. Private landholding patterns have changed considerably since 1978. In general, owner operation has decreased and sharecropping has increased. The Swedish Committee on Afghanistan (SCA) reports that 17 percent of Afghanistan's farmers are now sharecroppers and 4 percent are tenants, a considerable decline since 1978. The SCA study suggests that sharecropping declined up until 1978 and increased thereafter. National average figures are given in the following table. ${ }^{2}$

${ }^{2}$ Swedish Committee on Afghanistan, The Agricultural Survey of Afghanistan, First Report, May 1988, Annex 2, Table 4. 


$\begin{array}{lccc} & 1978- & 1987- & \text { Percent } \\ & 1979 & 1988 & \text { Change } \\ \text { Owner Occupier } & 80 & 56 & -30 \\ \text { Sharecropper } & 21 & 26 & 24 \\ \text { Abandoned Farms } & 7 & 31 & 342\end{array}$

Land has been the most common collateral for loans in both the private and public sectors. The Public Sector Agricultural Development Bank of Afghanistan (ADBA) originally required a land mortgage or a promissory note from a landholder other than the borrower as security for term loans. It normally insisted on a mortgage registered with a court of law. The ADBA had the right, at least in principle, to sell the lands, in case of default, without the borrower's having any further recourse to courts. In practice, cultural constraints and the inadequacy of the legal system obstructed the sale of land to recover loans. Private lending to farmers was typically done by mortgaging the land to the lenders, but here, unlike in the case of banks, enforcement was by custom rather than through court proceedings. Title was typically transferred for the duration of the mortgage.

Traditionally, land tenure in Afghanistan was established and maintained by four mechanisms: (1) local consensus, (2) Islamic law (sharia), (3) self-help and (4) government legislation. Nominally, the rules were set by the sharia and modified by explicit legislation and local custom or consensus. However, local consensus - the ongoing corpus of folk agreement based on collective understanding-provided the basis for day-to-day stability. Whether or not up-tc-date title existed in written form, a given piece of inhabited, cultivated, or pasture land was, in virtually all cases, recognized as belonging to a particular owner. In certain Pashtun tribal areas, these understandings were periodically ratified by jirgas, or tribal assemblies. Before 1978, and particularly during the Daoud era (1973-1978), a cadastral survey was attempted in order to codify the local consensus and embody it in legal documents, but little progress was made. In 1978 it was estimated that only 20 percent of landowners had title to their land and only 5 percent were covered by the cadastral survey.

The formal procedure involved in getting a land transfer confirmed by a court of law was time consuming and expensive as was the procedure for registering a land title in the Register Office (Amlok). The accuracy of documents was often questionable. Various and conflicting standards of land measurement were used (e.g., jerib, tukham raiz, qolba, and paikal). In certain areas, irrigated land was measured by the quantity of seed needed; in other areas it was measured by water rights.

In 1970, the Daoud government passed a series of laws dealing with land ownership and registration, including a graduated land tax law and a land reform law. The land reform law, which became effective in July 1976, 
prescribed ceilings on land holdings and set up procedures to transfer excess land to poor and landless farmers. After the coup in December 1978, the new Kabul Government issued Decree No. 8 with the objective of equalizing land ownership and broadening its own political base. The decree set a ceiling of 6 ha. for first grade land that could be owned by landlords. Any surplus was to be confiscated without compensation to the owners and given to landless farmers and nomads.

It appears that very little land was actually distributed under the decree because of the weakness of the Kabul Government as well as the confused state of land tenure. Many farmers refused the allotted land, either because of fear of the former landlords' power or because they believed the reform was immoral.

The 1978 decree was amended in 1983. Tribal, political, and military leaders who sided with the Kabul regime were either given back their land, or were paid an attractive price for it.

From 1987 to the present, the effective control by the Kabul regime has declined dramatically. Abandoned arable lands have been occupied by mujahidin commanders and by the limited number of returning refugees.

The primary category for state and communal lands is forests and pastures. Uncertainties about the precise status of these lands have led to serious problems.

Utilization of forests was always inefficient; 60 percent of the availeble wood is estimated to be wasted. The current rate of deforestation is unknown. However, even before 1978, the rate of felling was estimated ai about 1 million $\mathrm{cm}^{3} /$ year, substantially above the annual growth rate. Official Kabul Government estimates now place deforestation at 10,000 to 20,000 ha./year. The situation of the relatively small pistachio forests has improved and production has been sustained. If no action is taken, the Kunar and Paktia forests will be completely destroyed in the next 3 to 4 years-imposing high social costs such as unemployment, erosion, and worsening climate.

As far as the roughly 40 million ha. of pasture is concerned, grazing has continued to be uncontrolled and will be beyond the carrying capacity of the land when the country's herd size is restored, especially in areas close to water sources and during droughts, which occur on the average of once every 2 to 4 years.

The potential for land tenure difficulties is immense; before they emerge, it would be useful to prepare some of the infrastructure-institutional and legal-to address them. 
The problems to be addressed will depend to a considerable extent on the existing political scenario. If resettlement includes some participation by the -present Kabul regime, consideration will have to be given to the status of land reform and the redistribution the government has pursued. If the countryside is dominated, as seems likely, by mujahidiin commanders, the status of the land redistributions and changes in tenure conditions that they have undertaken piecemeal will have to be addressed.

Land tenure problems will be exacerbated by Afghanistan's ethnic heterogeneity. In Kunduz and other parts of the north, for example, Pashtuns have left their agricultural land, much of it acquired with government sponsorship over the last century, in larger numbers than the older settled, non-Pashtun groups. Some of these other groups, especially the Uzbeks, have long regarded many of the Pashtun holdings as illegal and inequitable. Anecdotal reports have reached Peshawar of land around Khanabad that has already been confiscated by mujahidiin commanders, even in instances in which the Pashtuns have cooperated with the jihad.

In Hazarajat, in the center of the country, the Hazaras asserted their authority early in the war and denied Pashtun nomads the grazing rights that had been granted by King Abdur Rahman Khan a century ago. A senior Afghan nongovernmental organization (NGO) official in Peshawar, himself a Pashtun, reported repeated Pashtun and Hazara clashes in Uruzgan.

Irrigation-its extent and state of deterioration-is also likely to exacerbate the land tenure controversy. The patterns of land use may have to be altered, radically revaluing traditional land rights and creating potential causes for conflict. Those who formerly had valuable land may discover that their land has lost its fertility and may try to apply to the tribal community to reallocate land in their favor.

Increased mortality as the result of more than a decade of war will also exacerbate land disputes. The large number of widows with young children, and sometimes no adult male kinsmen, although guaranteed land by the sharia, may have difficulty enforcing their rights.

Efforts to resolve these problems will be complicated by the lack of a land registration system and unclear land titles. Traditionally, conflicts about land or water rights would have been resolved by jirgas or councils of village elders, but they may now be in a state of disarray in much of the country.

Income and poverty are linked with irrigated land per capita. The return of 4 to 5 million cross-border refugees will increase population density and consequently upset the economic balance in some areas. The return of internal refugees will further exacerbate matters. Many of the refugees have been dependent on international relief organizations for several years, and will have to become reaccustomed to earning their own living. 
The majority of returning refugees will be sharecroppers or subsistence farmers in rural areas who will benefit little from conventional, commercially oriented production programs. Specially targeted measures may be required to assist them. Under the best of circumstances, agricultural incomes that were low by world standards before 1978 will be lower still.

Searching for higher returns, some smaller farmers in Helmand, Badakhshan, Kunar, and Nangarhar had begun to cultivate poppy even before the war. Best estimates are that before 1978, between 200 and 400 tons of opium and 500 tons of cannabis were grown annually in Afghanistan. The volume of opium being grown has increased, and vigorous measures will be required to control it.

Resettlement problems will differ between three classes of returnees: those who were landless sharecroppers, small subsistence farmers who own their own land, and larger landlords. Programs to restore agricultural production-by rebuilding transportation and irrigation infrastructure, restocking livestock, and reequipping farms-are being undertaken and must be continued. These efforts will be supported by programs to assist in clarifying land tenure rights.

Some legislation will be required to codify land tenure rights; however, for the foreseeable future, it will be necessary to rely to a considerable degree on local institutions to handle land tenure matters on a case-by-case basis. The situation will be most delicate when it comes down to the issue of determining the legitimate claimants to lands that have been confiscated during the various land reforms, especially those of 1976 and 1978, or by mujahidiin commanders.

When workable local shuras exist they can presumably judge according to sharia and custom. When they do not exist, or when several shuras' jurisdictions conflict, a central government will have to step in and use its statutory standards and cadastral system.

Because considerable problems can be anticipated in connection with land ownership when large-scale resettlement of refugees occurs, USAID might consider several types of involvement.

As far as private lands are concerned, some assistance might be provided on a pilot basis to improve the cadastral system. Some pilot surveys might be undertaken, partly with a view to training a cadre of survey workers who might be available either to work in a new governmental cadastral survey or to work as private surveyors, assisting landowners and village communities in establishing their records of land rights. This pilot activity could be undertaken as a free-standing project or in collaboration with some NGO or local government resettlement project. 
Because these activities will have to be conducted locally, various approaches might be tried; for example, the Mission might consider explicitly designing its programs on an experimental basis: a certain number of villages could undergo a full survey; in other villages the survey could deal only with private lands; and in others a "rough and ready" registration of titles could be done leaving others untouched.

There is little likelihood that any formal rearrangement of land titles or land reform will occur in the near future; however, some de facto tenancy reform has already been reported. It might be desirable to combine some of the pilot surveys with the recording of written leases as a means of protecting the right of tenants and landlords. A number of the commanders have reportedly imposed limits on landlords' shares, and a new central Afghan government may seek to do so as well. There is a need to provide some security of tenure to provide incentives for agricultural investment and production.

Further, USAID might insist that village communities regularize their land tenure and water usage arrangements as a precondition for receiving assistance. Otherwise, it is quite possible that tenurial and water problems will undercut the possibility for agricultural growth. These village communities might be required to begin a cadastral survey to document land and water rights.

In theory, it might be desirable to move from the current dominance of sharecropping arrangements to fixed-rent leases, giving a greater incentive to the tenant to undertake agricultural investment and to the landlord to increase his take by lending money for investment in agriculture. However, experience in other countries suggests that lease arrangements respond to the ease or difficulty of supervision of agriculture and are difficult to manage by decree.

Somewhat easier to manage than tenancy reform is the consolidation of scattered plots, which turns out to be extremely popular in irrigated areas in some countries because it permits the enhancement of production levels. Such consolidation, however, can be accelerated by the development of a land surveyor who can make the reasonably accurate assessment of land value that is required (Oldenburg 1990, pp. 183-195).

Public lands are an important and more easily addressed subject than are private land rights, at least they will be when a new central government emerges in Kabul. A cadastral survey is essential in order to prevent the incursion of private parties on public lands. Assistance to local groups and shuras might again be predicated on their surveying public lands and using the skills of the newly trained surveyors that were developed in the private survey effort. 
Arable lands owned by the state, beyond a prudent minimum that needs to be retained for public purposes, could be distributed to the landless as a. way of reducing pressure on the land.

In responding to the objectives of Delivery Order 13, this report presents and overview of land ownership in Afghanistan before the 1978 invasion and the year following the war. Following the introduction (Chapter 1), Chapter 2 outlines the general agricultural situation in Afghanistan and the role of land ownership in the country. Chapter 3 describes forms of private land ownership, relationships between land ownership and credit, and procedures for adjudicating land ownership problems. Chapter 4 describes the situation of public and communal lands, the environmental concerns connected with the war, and potential refugee resettlement. Chapter 5 describes opportunities for USAID involvement in dealing with the problems connected with land ownership. 


\section{1 \\ INTRODUCTION}

\section{Objectives}

This report was prepared in response to the O/A.I.D./Rep under Delivery Order No. 13 of the Afghanistan Studies Project. The objectives of the delivery order are to

1. Describe the framework of law, custom, and practice applicable to public, private, and common ownership of land in Afghanistan.

2. Identify types of community disputes concerning land ownership likely to arise under the present circumstance of relatively slow refugee return and suggest possible means for the resolution of such disputes. (This may gain increased importance in the wake of the capture of Khost when the possibilities for refugee return have been enhanced.)

3. Analyze issues of land tenure as they are likely to be affected by the return of substantial numbers of refugees and the capacity of existing Afghan institutions to deal with the issues arising from refugee resettlement.

4. Describe the likely impact of refugee return and of customary practices with respect to re-establishing or acquiring land ownership.

5. Describe the likely impact of refugee return on immediate prospects for reforesting traditionally forested areas of Afghanistan.

6. Identify and analyze opportunities for A.I.D. project and program interventions in advance of and during refugee return. 


\section{General Context}

- Afghanistan is primarily an agricultural country. Agriculture accounts for 45 percent of GDP. Even after 12 years of war, Afghanistan is still a highly traditional society in which clan and family are very important. Land ownership is part of a seamless web that includes the legal arrangements for local politics, land title, water use, social hierarchy, and many other arrangements that govern the use of the land and, in an agrarian society such as Afghanistan, the economic life of the country. The precise terms of control over land reflect rather than determine the local social power structure. Any change in land tenure requires a change in the structure of social power (Warriner 1962; Herring 1983).

As Feder and Feeney (1991) state in their recent review of the significance of land tenure arrangements, economic and social institutions are of three types: "constitutional order, institutional arrangements, and normative behavior codes." They characterize land tenure as an institutional arrangement; however, this is an oversimplification because land tenure arrangements correspond to specific constitutional orders and behavior codes.

The new institutional economists have taught us to view the types of economic institutions as responding not only to a specific historical evolution of legal forms but as themselves the product of demand and supply forces driven by the desire of individuals and groups to maximize their welfare. To quote more extensively from Feder and Feeney (1991):

In the early stages of agricultural development, land rights may be split between individuals and the community. Individuals are assigned use rights (which can be long term and inheritable), although the right to sell land or transfer the use right to nonheirs is retained by the community. Under circumstances where endowments are similar across households and land is abundant, such arrangements provide incentives to individuals to exert effort in tilling land and preserving fertility (through secure and inheritable use rights), yet they minimize social tensions. Social unrest may emerge when individuals lose their land rights, especially to nonmembers of the community, creating a landless class. When technology advances, however, and endowments of labor and other productive assets differ among households, the lack of transferability of property rights may adversely affect productivity. Efficiency considerations thus motivate changes both in the constitutional order and institutional arrangements relating to land rights. [emphasis added]

As time passes and society evolves:

Increasing population density, appreciations in the agricultural terms of trade, and technological change, which made investments in land quality more profitable, have enhanced the benefits from creating more precise private property rights in land.... The demand for institutional arrangements to describe 
and enforce property rights in land with more precision is thus a common feature of many developing countries.

Such precision is demanded as a way to increase incentives for land investment and conservation, facilitate credit transactions, permit flexible transfer of lands to those with higher productivity uses, and, not least, minimize the turmoil that often surrounds the determination of land titles.

Afghanistan had been moving toward greater precision in the 1970s, only to have the process interrupted at an early stage by the coup and ensuing civil war and invasion from 1978 onward. These events have exacerbated the problems of land ownership by creating new claims and destroying former institutions for enforcing rights to land. 


\section{2 \\ CHARACTERISTICS OF LAND OWNERSHIP IN AFGHANISTAN}

\section{Classifications of Land by Productive Use}

Afghanistan covers 65.3 million ha., of which only 12 percent or nearly 8 million ha. is arable (Table 1). The remaining 57 million ha. consists of forests, pastures, and mountains. Of the 8 million ha. of arable land, only 4 million ha. or 50 percent is cultivated in a normal year.

Before 1978, about 2.6 million ha. was reported to be irrigated; about 1.4 million ha. of this land received adequate water for year-round cultivation, and another 1.3 million ha. of wheat, oilseeds, melons, and barley was dry farmed.

Between 1978-1979 and 1987-1988, the area irrigated declined by 21 percent and the nonirrigated area declined by some 30 percent as a result of abandonment, inadequacy of farm power, and destruction of irrigation facilities in the rural areas. The largest decline in cultivated area (50 percent) is reported to have occurred in the southwest region (Ghazni, Helmand, Kandahar, Nimroze, Paktika, Uruzgan, and Zabul provinces). In the southeast region, which comprises the provinces of Konarha, Laghman, Nangarghar, and Paktia, the area cultivated declined by only 3 percent. Over the last 3 years, some of the abandoned land has been returned to cultivation, yet the total area cultivated in 1989-1990 was about 21 percent less than that cultivated in 1978-1979 (Table 2).

Before 1978 only 25 percent of irrigated land was in the southeast and southwest compared with about 43 percent in the north and northeast. The major portion of the arable land in the southwest and southeast was irrigated; that is, there was very limited dry farming. Thus southeast and southwest Afghanistan (see Map 1) has been far more vulnerable to variations of crop production through destruction of traditional irrigation systems than have other parts of the country. 
Table 1. Shift in Use of Land Resources, 1978-1979 to 1989-1990 (thousand ha.)

\begin{tabular}{|c|c|c|c|c|}
\hline \multirow{2}{*}{ Land Classification } & \multicolumn{2}{|c|}{$1978-1979$} & \multicolumn{2}{|c|}{$1989-1990$} \\
\hline & Area & Percent & Area & Percent \\
\hline $\begin{array}{l}\text { Arable land } \\
\text { Cultivated }^{a}\end{array}$ & 7,910 & 12.0 & 7,910 & 12.0 \\
\hline \multicolumn{5}{|l|}{ Irrigated } \\
\hline Wheat & 1,300 & 2.0 & 1,030 & 1.6 \\
\hline Other cereals & 834 & 1.3 & 742 & 1.1 \\
\hline Fruits and nuts & 141 & 0.2 & 137 & 0.2 \\
\hline Industrial crops & 134 & 0.2 & 67 & 0.1 \\
\hline Other & 170 & 0.3 & 149 & 0.3 \\
\hline \multicolumn{5}{|l|}{ Nonirrigated } \\
\hline $\begin{array}{l}\text { Wheat } \\
\text { Other }\end{array}$ & $\begin{array}{r}1,048 \\
248\end{array}$ & $\begin{array}{l}1.6 \\
0.4\end{array}$ & $\begin{array}{l}715 \\
216\end{array}$ & $\begin{array}{l}1.1 \\
0.3\end{array}$ \\
\hline Total cultivated & 3,873 & 6.0 & 3,056 & 4.7 \\
\hline Uncultivated & 4,037 & 6.0 & 4,854 & 7.3 \\
\hline Total uncultivated & 4,037 & 6.0 & 4,854 & 7.3 \\
\hline $\begin{array}{l}\text { Forest } \\
\text { Pasture } \\
\text { Mountains and desert }\end{array}$ & $\begin{array}{r}1,900 \\
40,000 \\
15,453\end{array}$ & $\begin{array}{r}3.0 \\
61.0 \\
24.0\end{array}$ & $\begin{array}{r}1,900 \\
40,000 \\
15,453\end{array}$ & $\begin{array}{r}3.0 \\
61.0 \\
24.0\end{array}$ \\
\hline Total land area & 65,263 & 100.0 & 65,263 & 100.0 \\
\hline
\end{tabular}

${ }^{a}$ Approximately 26 percent of the irrigated land and 40 percent of the nonirrigated land are fallow.

Sources: "Afghanistan: Opportunities for Agricultural and Rural Development, Sector Report", World Bank, 1975, page 8. "Afghanistan: Journey to Economic Development," Vol. II, Table 7.1. Statistical Yearbook, Central Statistics Organization, 1989, page 103. 


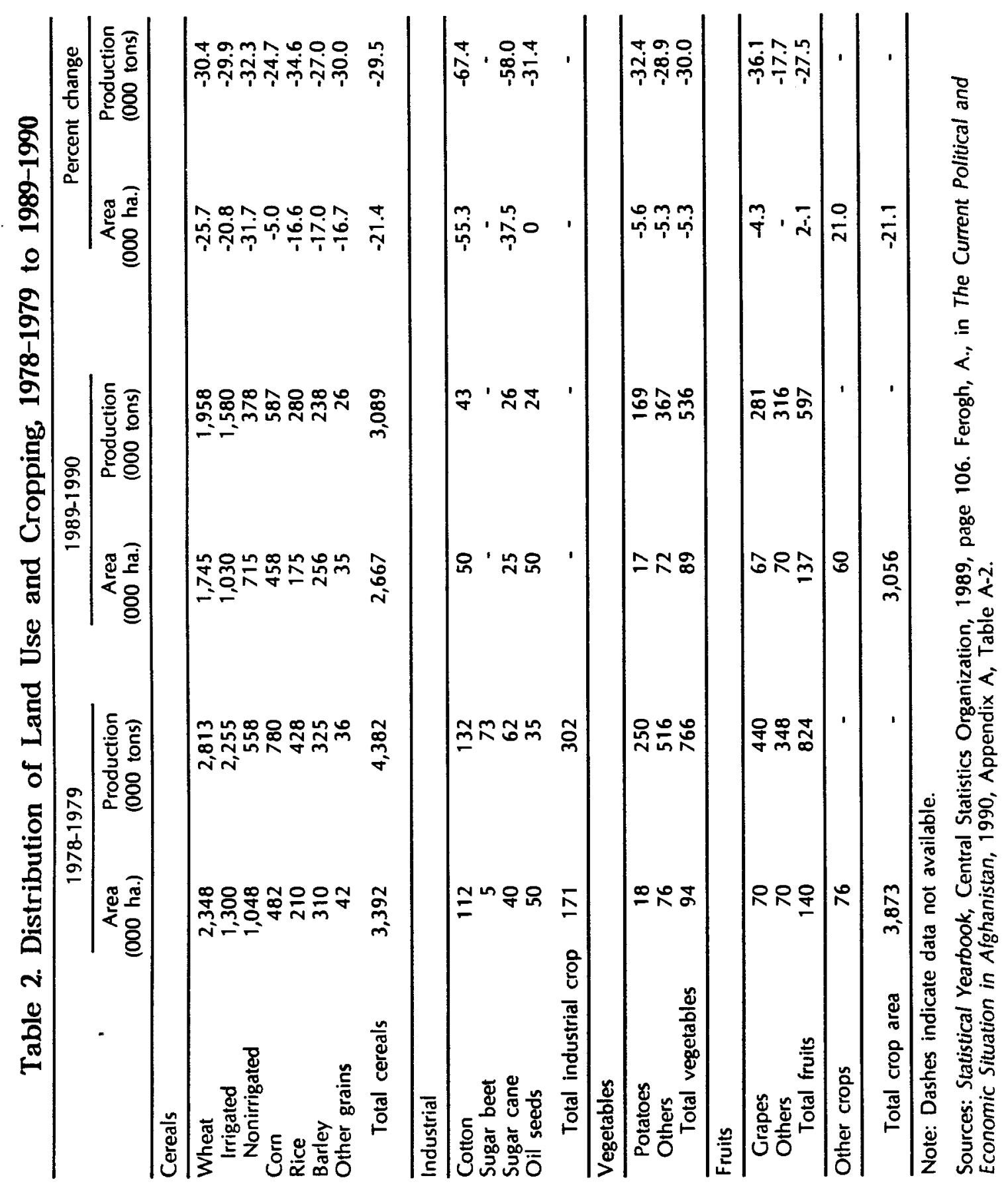




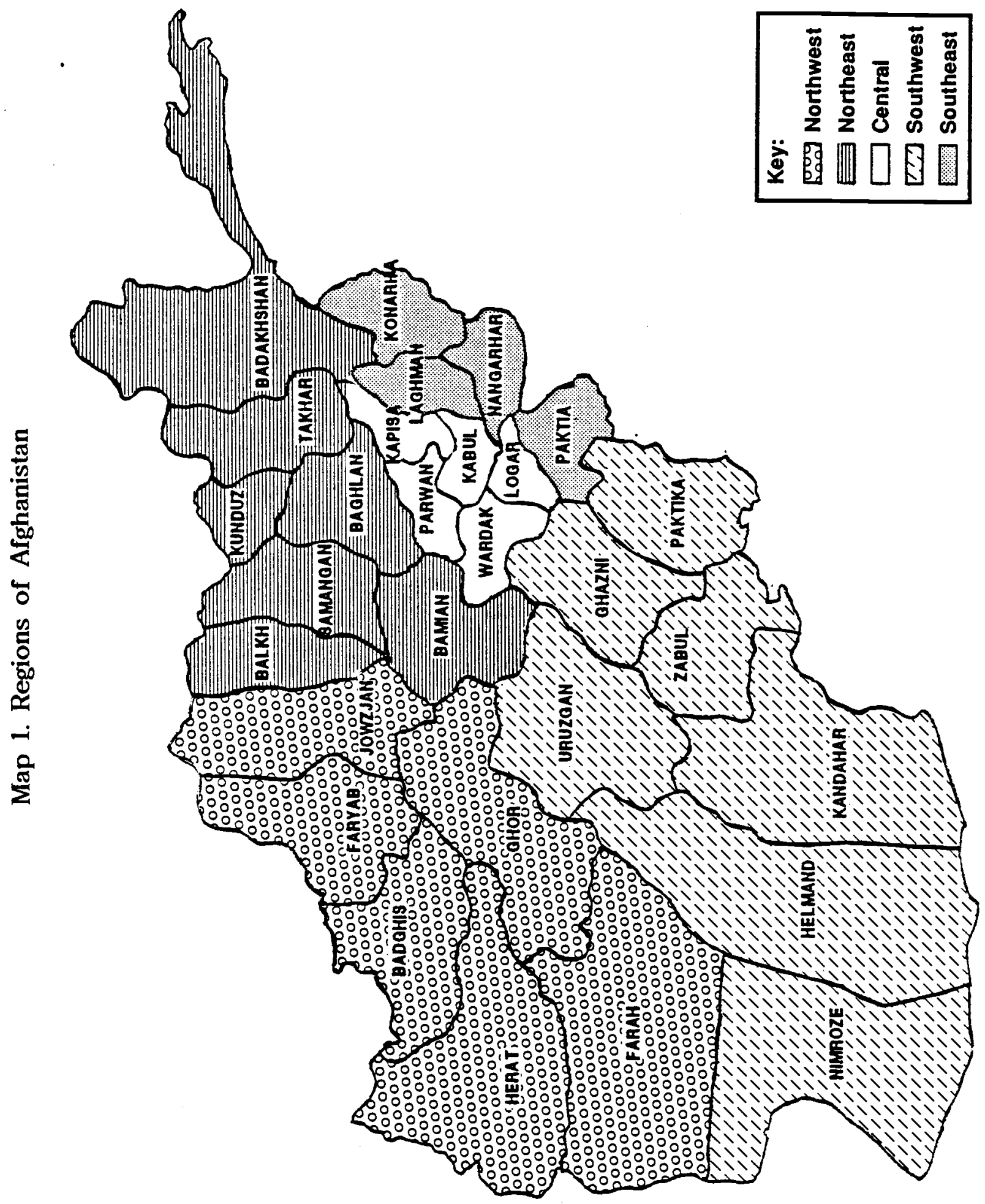


Although the cultivated area has declined by about 21 percent since 1978 , the cultivation pattern has remained almost unchanged. Cereal production accounts for 87 percent of cultivated land, with wheat occupying 57 percent.

Of the 1.7 million ha. under wheat cultivation in 1989-1990, nearly 1 million ha. or 60 percent was irrigated. Between 1978-1979 and 1989-1990, the total area under wheat cultivation declined by 25 percent, and average yield declined by 5 percent. As a result, total wheat production declined from 2.8 million tons to less than 2 million tons.

In the north and northeast regions, the total area under wheat cultivation is reported to have dropped by 22 and 26 percent, respectively. It is important to note that these regions contained about 53 percent of the total area under wheat. In the southeast, the total area under wheat cultivation has remained constant.

At present wheat is in short supply, and a major part of the country's wheat requirements is met through imports. Annual imports are estimated at more than 400,000 tons.

Maize was grown on 482,000 ha. in 1978-1979 and on 458,000 ha. in 19891990, a decline in acreage of 5 percent. Maize is cultivated throughout the country, particularly in the provinces of Baghlan, Helmand, Kabul, Laghman, Logar, Nangarhar, and Parwan and the city of Mazar-i-Sharif (Balkh). Total maize production decreased from 780,000 tons in 1978-1979 to 587,000 tons in 1989-1990 (25 percent), mostly because of a reduction in the area under cultivation. The decline was spread evenly across the country.

Rice was grown on 210,000 ha. in 1978-1979 and 175,000 ha. in 1989-1990, a decline in acreage of 17 percent. Rice production declined from 428,000 tons to 280,000 tons. Rice cultivation is concentrated in Baghlan, Takhar, and Kunduz. Rice is also grown in Nangarhar and Laghman in the southeast and Herat in the northwest.

Before 1978, cotton was a major cash crop, especially in Baghlan and Takhar in the northeast, Balkh in the north, Herat in the northwest, and Helmand in the southwest. In 1978-1979, cotton production was 132,000 tons on 112,000 ha.; by 1989-1990 acreage had declined by 55 percent and production had declined by 67 percent. Cotton was also grown on a small scale in Parwan for home consumption.

Before 1978, sugar beets were grown on 5,000 ha. (by 3,000 farmers) in Baghlan. In 1978-1979, 73,000 tons of sugar beets were produced. In 1989 only 400 ha. of sugar beets was under cultivation for home consumption, and apparently no sugar is currently being produced commercially. 
The most important vegetables grown in Afghanistan are onions, potatoes, and tomatoes, which are grown in Nangarhar, Kabul, Ghazni, Parwan, Maidan (Wardak), and Bamian. Before 1978, vegetable production was estimated at 766,000 tons on approximately 94,000 ha., with potatoes accounting for roughly 20 percent of production. Bamian, Maidan, Ghazni, and Kabul had the best environment for potatoes, which were also grown as a winter crop in Laghman. Cauliflower was grown in the eastern provinces and as a summer crop in colder areas. The area may well have been maintained since then, but total vegetable production has apparently fallen to 30 percent as a result of various plant diseases.

A large number of perennial crops are grown. Grapes, nuts, pomegranates, melons, citrus fruits, pears, and apples are grown in Kandahar, Parwan, Nangarhar, Kabul, and Balkh. Mulberry is grown in Kabul and in the western provinces. Walnuts are concentrated in Badakhshan, Kabul, and Parwan.

Fresh and dried fruits and nuts still constitute an important exportthrough both formal and informal channels. Before 1978, the area under fruit cultivation was estimated at 140,000 ha.; grapes accounted for one-half of this acreage. The area cultivated in fruit has probably declined only slightly since 1978 but total production is down 28 percent because of diseases, deterioration of irrigation channels, and disruption in marketing channels. (See Map 2 for areas of production of maize, rice, cotton, sugar beets, vegetables, fruits, and nuts.)

About 42 million ha. is forests or pastures. Some 1.9 million ha. or 2.9 percent of the land area was forest before 1978; the Kabul regime reports a figure of 1.7 million ha. today. Forests are of two kinds: cedrus/pine/oak and pistachio. For lumber, there are first-rate commercial cedrus/pine/oak forests in Paktia and Kunar provinces of about 450,000 ha. each. These forests represent a wood reserve of 30 million $\mathrm{cm}^{3}$. Fast-growing poplar plantations exist in Kabul, Maidan, Parwan, and Ghazni.

In Kunar, the logs are transported to the nearest river by hand where they logs are then floated down the river to Pakistan. ${ }^{3}$ In Paktia logs are transported by camels and trucks.

The pistachio forests are situated in the west and northwest, particularly in Badghis, Faryab, and Samangan. There are also mixed forests of pistachios, pinus halepensis, and junipers in these provinces. The Food and Agriculture Organization (FAO) estimates annual production at 1,400 tons of pistachio nuts, and production has probably been sustained at this level since

\footnotetext{
${ }^{3}$ Article 31 of the water law prepared by the Kabul Government permits transport of timber by water provided that the applicant gets a permit from the government, but this is widely ignored.
} 


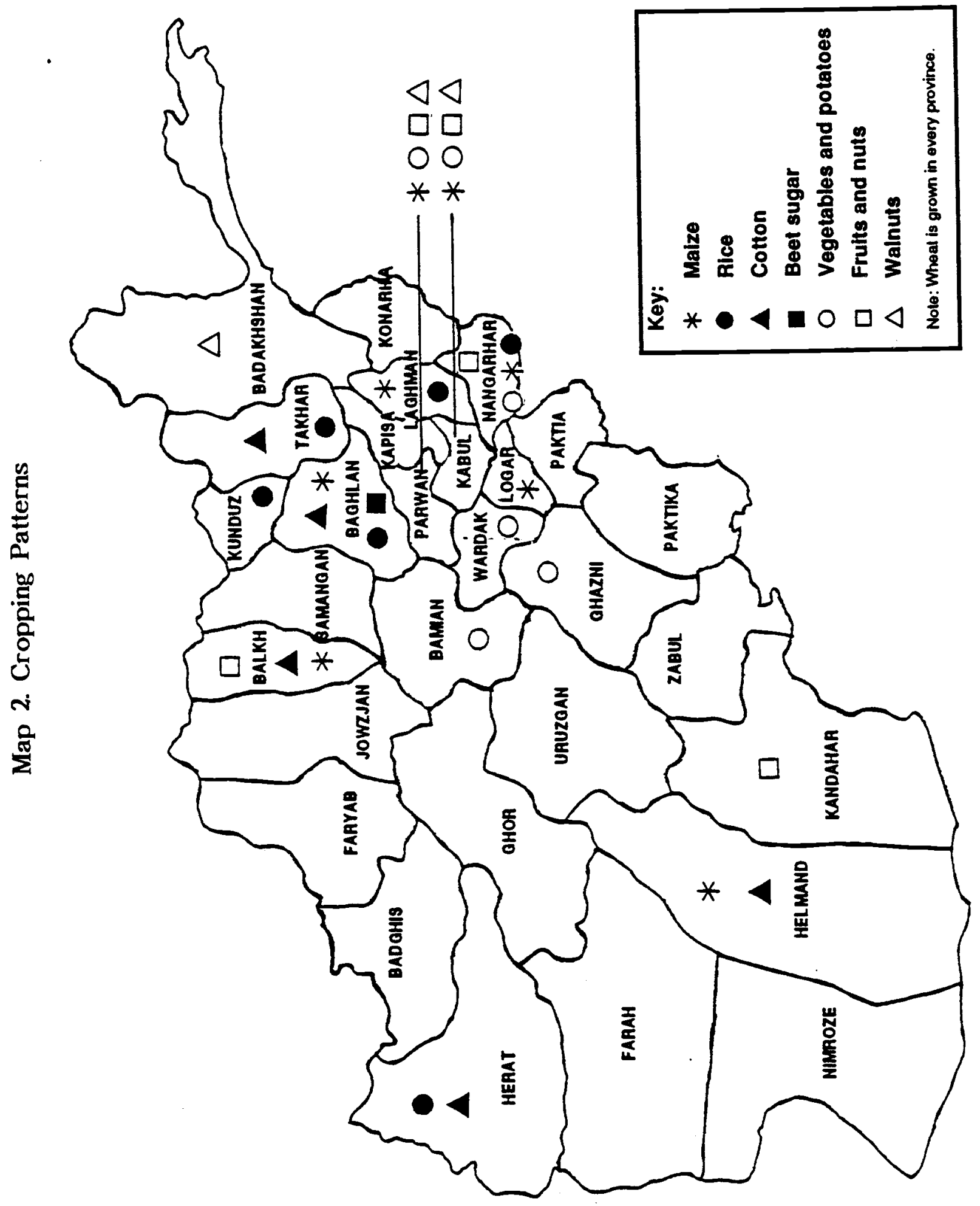


1978. An edible nut, jalghoza, covered a large area in Paktia. (See Map 3 for locations of cedrus/pine/oak and pistachio forests and poplar plantations.)

Pastures occupy about 40 million ha. or nearly 60 percent of the country's area. Of this acreage, 15 million ha. is spring pasture in the northern and northwestern plains and the southwestern lowlands, and 25 million ha.is summer pasture in the highlands of Hazarajat and Badakhshan.

\section{Principal Forms of Land Tenure}

There are four broad categories of land tenure: (1) no ownership-land open to all; (2) state ownership; (3) communal ownership-limited to a tribe or community; and (4) private ownership.

Most of Afghanistan's arable land is privately owned. Both sharia (Islamic law) and the constitution provide for extensive state land holdings. In theory, the state owns three categories of rural land: (1) Waqf Muslim religious trust land, which was nationalized in the 1890 s by King Abdur Rahman Khan; (2) the floodplain that borders the south shore of the Oxus River (Amu Darya) from Samangan upstream, which is government land in principle; and (3) all wasteland, forests, and pastures, which the government claims but has made little attempt to restrict or regulate. According to sharia, lands that are neither privately owned nor cultivated belong to the state. In addition, the state has always had various claims to two categories of arable land: state farms and wastelands reclaimed by government irrigation projects.

Arable public lands were frequently let on long-term lease for cash rent by the government itself, although no law exists that authorizes these leases. By contrast, private land is rarely leased for fixed rent. A portion of privately owned land-previously about one-third, currently one-sixth-is sharecropped. A considerable portion of privately owned land is mortgaged, with payments that are quite similar in function to rent in that the land actually is transferred to the lender and the borrower pays the lender for its use. Other private lands are cultivated by laborers under supervision of the landowner or by the landowner himself.

Despite the state's claims, many of the state lands, especially forests and pastures were, in fact, communal lands, controlled and used by longaccepted custom by one or another tribal group with rights to exclude others.

Afghan private landholdings even in 1978 were small and fragmented and their distribution unequal. Private landholding patterns have changed considerably since 1978. In general there has been a decrease in owner operation and an increase in sharecropping. 


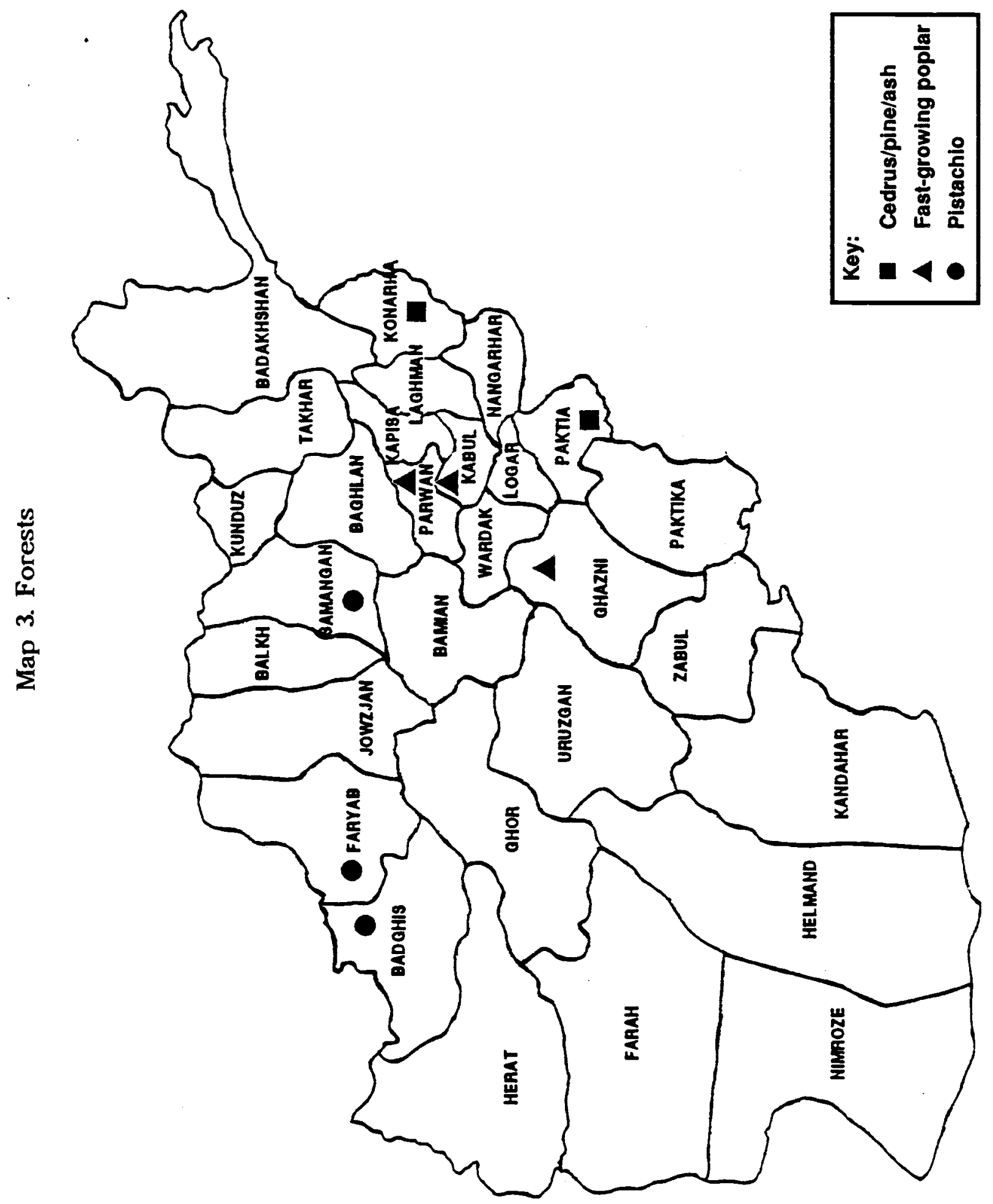


Afghanistan's total arable land area of 8 million ha. had to support a 1976-1977 population of 14 million. If 10 million people were in rural areas this would give a per capita figure of 0.8 ha. A 1967 land survey indicated that some 2.2 percent of landowners owned 42 percent of the cultivated area, whereas 40 percent of all landowners held less than 4 percent of the cultivated land. The gini coefficient of landholding distribution was 0.66 on this basis, or 0.57 according to the Kabul regime. However, surveys conducted during the 1970s indicated a mean farm size of 2.5 to 3.5 ha. with the majority of the 1.2 million farm households having holdings ranging from 0.5 to 6 ha. Recent reports indicate that the average size of landholdings has increased since 1978, but any figures are necessarily questionable. A close examination of the figures from the Swedish Committee on Afghanistan (SCA) shows that the average farm size is now about 4 ha. but that variation in size is quite large.

On the other hand, very large-scale landowners were always few. Dupree (1980) reports that only 30 landlords were reported to have more than 200 ha. Numerous observers believe that this figure is too low because many of the landowners have fled the country. The average number of farms per region is given in the following table from the SCA, The Agricultural Survey of Afghanistan, First Report, Annex 2, Table 4, May 1988.

Absolute numbers from survey

1978-1979

1987-1988

Percent change

Owner-occupier

Sharecropper

Abandoned farms

$\begin{array}{rrr}80 & 56 & -30 \\ 21 & 26 & 24 \\ 7 & 31 & 342\end{array}$

About half a million people were estimated to be landless and working primarily as sharecroppers and farm laborers before 1978. These sharecroppers and laborers typically worked for larger farmers. Sharecroppers in particular were estimated to have cultivated 40 to 50 percent of the country's lands. ${ }^{4}$ They were referred to by various names: dehqan if they cultivated field crops, baghban if they cultivated horticultural crops, kishtagar or bazgar in the west of the country, depending on whether they supplied oxen and implements or only labor. Different categories of sharecroppers received onethird to one-seventh of the crop, depending to some extent on whether they supplied their own oxen and implements.

Leasing of farmland was on a much smaller scale than sharecropping. It was estimated that 3 percent of the total land farmed annually was leased. Government and other institutions typically leased on the basis of open bidding, whereas private owners generally did not. Government leases were

\footnotetext{
${ }^{4}$ These figures are taken from the 1963 Survey of Population and Agricultural Characteristics cited in the bibliography.
} 
formal and written, whereas private leases were often informal and oral. The government also leased nonirrigated wasteland for periods of up to 20 years to provide incentives for investment in irrigation; this was particularly the case in Dashte Khoja Alwan in Baghlan and Dashte Bakwa in Farah.

Even though the modal holding was small, the size distribution appears to have been relatively skewed. Different studies have reported varying figures, but all have indicated that a small number of farmers owned a large proportion of the land. Smith et al. (1973) reported that a little more than 2 percent of the farmers are estimated to have owned 34 percent of farmed land. The accuracy of these figures cannot be determined because they are based on survey responses given by the farmers themselves and cannot be verified without a cadastral survey. In addition, the 1975 land reform law limited farmers to 20 to 30 ha., and many landlords had ostensibly distributed their holdings to various family members and other nominees. Some of this distribution was real and contributed to equalization as reported by Dupree (1980). Detailed studies, such as the one conducted in Nepal, have shown that farmers typically under-report their landholdings when there is no cadastral record but are more accurate when one exists (Stone 1984).

Landholdings are frequently highly fragmented. A farmer may hold his land in several different and separated pieces. This land division was exacerbated by the Islamic inheritance law (sharia), which distributes property to a large number of legatees-both sons and daughters. The operational holdings were continually subdivided, and, as in many traditional societies, one owner would have many scattered plots. Large amounts of land were tilled by sharecroppers or held under mortgages that amounted to tenancy.

This situation has changed considerably since 1978. The SCA collected general information on the number of sharecroppers in 1988 and on a more detailed basis in 1989. (See Table 3.) The results are somewhat contradictory. The SCA reports that there has been a decrease in owner operation and an increase in sharecropping since 1978. However, it reports that only 17 percent of Afghanistan's farmers are now sharecroppers and 4 percent are tenants. A 1963 survey reported that 13.8 percent of land was cultivated by sharecroppers; however, sharecroppers accounted for a larger percentage of cultivators. According to the SCA, there is no consistent difference in yields between owners and sharecroppers.

\section{Techniques for the Use of Land as Security for Debt}

Land has been the most common collateral for loans in both public and private sector lending. The Agricultural Development Bank of Afghanistan (ADBA) originally required a land mortgage or a promissory note from a landholder as security for term loans. It normally insisted on a mortgage 
Table 3. Estimated Distribution of Agricultural Land by Form of Tenure

\begin{tabular}{lcccc}
\hline Province & Sharecropped & Mortgaged & Owner operated & Other \\
\hline Kabul & 16.1 & 6.6 & 74.9 & 2.4 \\
Qandahar & 9.1 & 7.5 & 54.1 & 29.3 \\
Herat & 13.4 & 0.7 & 62.7 & 23.2 \\
Mazar-i-Sharif & 23.6 & 1.5 & 60.0 & 14.8 \\
Ningrahar & 5.4 & 43.6 & 45.1 & 5.9 \\
Paktya & 2.0 & 3.7 & 94.3 & - \\
Qataghan & 22.2 & 5.8 & 63.2 & 1.1 \\
Ghazni & 8.1 & 11.2 & 79.6 & 69.2 \\
Girishk & 6.4 & 5.7 & 18.7 & 14.3 \\
Farah & 24.1 & 11.2 & 60.1 & 21.8 \\
Maimana & 2.4 & 0.6 & 75.2 & - \\
Shibarghan & - & - & -7.4 & 5.1 \\
Badakhshan & 1.3 & 0.8 & 75.4 & 23.8 \\
Parwan & 5.8 & 9.1 & 80.0 & 1.1 \\
Bamiyan & 1.6 & 0.6 & 73.9 & 10.9 \\
Uruzgan & 13.3 & 5.8 & 79.8 & 20.2 \\
Ghor & 12.1 & 1.2 & 75.8 & 60.5 \\
\end{tabular}

Note: Averages are for all provinces except Shibarghan. Old province names are used.

Source: World Bank, May 12, 1977. Annex I, p. 15.

registered with a law court (Mahkama-e-wasayek). The ADBA had the right, at least in principle, to sell the lands in case of default without any further recourse to courts. In practice, cultural constraints and the inadequacy of the legal system obstructed the sale of land to recover loans.

Few landowners had registered land titles and could obtain these loans. Land fragmentation and the relation of land to undefined water rights also impeded this lending. As of 1977 the security requirements were as follows.

- Loans of up to Afs. 25,000 were granted against the security of a promissory note (hujat-e-tijarati) signed by the borrower and one guarantor with a registered land title.

- Loans up to Afs. 100,000 required a promissory note registered with the Directorate for the Registration of Lands (Amlak) or a competent court in addition to a guarantor with a properly registered land title.

- Loans greater than Afs. 100,000 had to be based on the mortgage of land worth at least $1 \frac{1}{2}$ times the nominal amount of the loan.

Short-term loans under the fertilizer program were secured by joint and several guaranties of groups of 5 to 10 farmers. The system was first introduced on an experimental basis in the Helmand Valley under the USAID- 
sponsored agricultural program and was refined and expanded by the ADBA in 1971 in connection with the Emergency Agricultural Production Program.

Although the group guarantee increased access to loans, it was still limited to landowners who had to demonstrate their ownership by submitting a current tax receipt. The extension agents of the Ministry of Agriculture also attested to the landownership of the applicant as well as his crop acreage. The tax receipts were certified for the group by an authorized representative of the Amlak while the village chief (malik) certified that the farmer lived in the village and the subgovernor certified the identities of the village chief and land office representative. The farmer did not require a registered deed (qabala).

ADBA procedures have not changed since implementation of the 1979 land reform, but its activities have been affected in other ways. The ensuing war has caused security and repayment problems, and lending has been curtailed. ADBA's loans declined from Afs. 1 billion in 1978-1979 to Afs. 0.144 billion in 1989-1990.

The Herat Livestock Development Corporation (HLDC) also granted credit on the basis of land-related security. In this case the community or a wealthy guarantor certified the borrowers title, specifically

- For loans of up to Afs. 200,000, a statement was required from the village authorities that no one else other than the loan applicant had any claim to the land. Promissory notes could be guaranteed by those with sufficient financial standing.

- Loans up to Afs. 300,000 required a court-registered promissory note with one guarantor of financial standing or with registered title to land.

- Loans greater than Afs. 300,000 required the joint liability of at least three residents of the same village, one of whom had to have a registered land title.

There is some indication that these terms led to more wide-scale lending than in the case of ADBA, but HLDC was closed after 1978 so the full effects of its policies have not been assessed.

Other government agencies also provided loans against the informal hypothecation of crops. These loans were extended to sugar beet and cotton cultivators by factories that purchased their outputs. They provided fertilizer and seed against the future delivery of crops as well as Afs. 1,500 per ha. in the form of a taqqavi loan for the farmers' cost in hiring additional labor. These credits were refinanced by the banks, especially ADBA. All of these crop-connected credits have declined sharply since 1978. 
For private lending, no formal collateral is involved, but the loans are paid in terms of crops or the right to use land. In late 1978, the Kabul government issued Decree No. 8, which was intended to reduce private land mortgages held on holdings of 3 ha. or less by waiving all tenant and sharecropper land-based debts to landowners. However, this decree has largely been ignored.

\section{Means of Adjudicating and Enforcing Rights to Land}

Traditionally, land tenure in Afghanistan was established and maintained by four mechanisms: local consensus, sharia, self-help, and government legislation. All of these mechanisms, as Herring (1983) and Warriner (1962) point out, operate in the context of local power structures and the consensus that legitimates them. Nominally, the rules were set by the sharia and modified by explicit legislation and local custom or consensus. However, local consensus - the ongoing corpus of folk agreement based on collective understanding-provided the basis for day-to-day stability. Whether or not an up-to-date title existed in written form, a given piece of inhabited, cultivated, or pasture land was, in virtually all cases, recognized as belonging to a particular owner. In certain Pashtun tribal areas, these understandings were periodically ratified by jirgas, or tribal assemblies. During the Daoud era (1973-1978) a cadastral survey was attempted, as noted earlier, to codify the local consensus and embody it in legal documents but little progress was made. The role of the government in ratifying and enforcing land tenure rights gradually increased until it was undercut after 1978.

Islamic law provided the basis for the transfer of land whether by sale, bequest, or inheritance. In many areas, sales were simply ratified by the same local consensus that played such a ubiquitous role. In areas closer to the centers of power, such transfers were often officially registered with the courts.

The majority of landowners do not have their lands registered in their own names. According to a report prepared in 1978, only 20 percent of all landowners had registered legal title to their land, and of these the number of landowners with titles listed in the cadastral survey was probably less than 5 percent. In view of the continued division of land in rural areas under the prevailing inheritance law and the reduced ability of government to register these transfers by inheritance, the proportion of landowners with registered land titles has probably declined sharply over the last 13 years.

Land tenure was enforced, fundamentally, by a readiness on the part of landowners to resort to a system of "self-help" generally served as a deterrent against casual usurpation, although more powerful neighbors often encroached on their less powerful neighbors. 
Disputes about landownership were typically settled informally, even though the result of the settlement might be registered with a court. Various types of tribal or clan leaders or elders might be called in to settle disputes. In the Pashtun tribal areas, the tribal chief would convene a conference or jirga, typically facilitated by a specialist in conciliation.

A number of documents existed for certifying land ownership. Formal deeds (qabalai sharayee) were the best and were formally approved and registered with the local court as well as the local finance office. Using this deed, the finance office collected land tax and certified landowners' creditworthiness. The vast majority of landholders, however, did not have such a deed and probably did not pay tax on their land.

There were also mortgage documents registered with the courts and used to transfer, on a temporary basis, land rights from one person to another. This document facilitated borrowing against land and allowed the lender to use the land until the loan was repaid.

The land division document (taraka khat) was initiated by a landholder and registered with the courts and the finance office as part of the process of distributing his land to his descendants. After the landholder's death, the heirs themselves could initiate this document.

The settlement of a land dispute was certified by a court called a ebrakhat sharayee. This mechanism was sometimes used to fraudulently acquire government land by manufacturing a false private feud and getting a court to certify its nominal resolution.

In default of the aforementioned documents, land tax forms with or without court documents were frequently used as evidence of land ownership.

Various informal, unregistered documents were also used as evidence of land ownership, with the signatures or fingerprints of all concerned parties, certification by two adjoining landholders and two other male witnesses, and the authorization of the village chief. These documents were often used as the basis for eventually securing formal court documents.

\section{Existing Formal Systems Pertaining to Land Tenure}

The formal procedure involved in getting a land transfer confirmed by a court of law was time consuming and expensive, as was the procedure for registering a land title in the Amlak. The accuracy of documents was often questionable. Various and conflicting standards of land measurement were used (e.g., jerib, tukham raiz, qolba, paikal). In certain areas, irrigated land 
was measured by the quantity of seed needed; in other areas, it was measured by water rights.

The government took a great deal of interest in formalizing land tenure. In the 1960s, it began to strengthen its cadastral survey in the Helmand, Kandahar, Ghazni, and Nangarhar areas with the assistance of USAID. A Cadastral Survey Training Institute was created in 1963.

The cadastral survey of Afghanistan was reorganized by the land law of 1965 (Qancon Survey Arazi). As indicated by a World Bank report in 1975, the aim was to survey 6 million ha. of agricultural land and 1.8 million ha. of pasture land. By the end of 1975, however, only about 400,000 ha. of agricultural land had been surveyed. In addition, a "quick and dirty" program covered the immediate registration without survey of approximately 2.8 million acres of arable land and 2.5 million acres of pasture; that is, the deeds were registered, but no field survey or appropriate land maps were developed.

Initially, the actual survey turned out to be only an inventory of land rather than a record of land ownership. The survey was based almost entirely on farmers' own reports, which tended to be underestimates for reasons noted earlier. No use was made of modern survey techniques or aerial photographs. The survey results were not useful for either land taxation or land reform. Later, aerial surveys and orthophoto plane production were introduced.

In response to these shortcomings, measures were taken to improve the situation, including the establishment in 1973 of the Afghanistan Cartographic and Cadastral Survey Institute by enactment of the Law of Survey, Settlement, and Registration of Land in 1976. The cadastral survey and cartographic institutes were merged. The new institute had 120 field parties spread throughout 10 areas of the country. It was estimated that at the rate of 30,000 . ha per party per year, it would take these field parties 20 years to survey the whole country.

The cadastral survey was controversial because it affected so many interests. In the debate over the land law of 1965, an interesting illustration of the political issues involved occurred. The legislative committee had reviewed the law and suggested that during the survey landowners present various landownership documents, including tax receipts. The larger landowners in the parliament objected. Many of them occupied land for which they had no documentation and on which they had not been paying taxes. However, Maulana Rashad, Secretary of the Parliament and himself a large landlord,

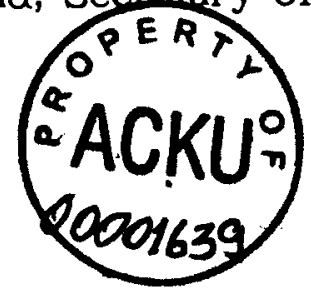


proposed that "prescriptive rights" also be taken into account, nullifying the narrower standards in the law.

By 1976 about 20 percent of Afghan landowners had officially registered titles (Third Appraisal Report 1977). The government passed a series of additional laws dealing with land ownership and registration, including a graduated land tax law and a land reform law. Before 1975, land was divided into three quality classes for land tax purposes on the basis of a classification undertaken in the $1920 \mathrm{~s}$. The tax rates ranged from Af. 0.5 per ha. for poor lands to Afs. 30 for good land.

Although the land tax was doubled in the mid-1960s, no changes in assessment had been made for nearly $\mathbf{5 0}$ years. This was partly the result of political pressure from landlords who often paid low taxes.

In 1976 a graduated land tax law was introduced by the government to deal with assessment more systematically. The new tax law required all landowners to submit tax declarations, specifying for each plot of land the requisite data to enable the tax authorities to assess it, even though the government realized that, in the long run, a cadastral survey was required.

The country was divided into several tax zones, and each taxpayer was required to declare all of his landholdings in the zone where his largest plot was located. The law divided land into three broad categories and seven grades on the basis of irrigation capacity, productivity, and average price and location.

Certain temporary and permanent exemptions were granted by the law. Tax rates were graduated according to the taxpayer's total holdings, and holdings worth the equivalent of 0.4 ha. or less were exempted. The tax rates ranged from Afs. 225 per ha. of first grade land equivalent to Afs. 2,000 for holdings greater than 200 ha. of first grade land equivalent. As is usual in this type of ceiling legislation, the limits were stated in terms of first grade land, and larger areas of inferior land were permitted and rules enacted for how the limits were to be adjusted for inferior land quality. Restrictions were imposed on land transfers. The land to be transferred had to be legally registered, taxes paid up, and the area of land to be transferred clearly specified. Lands that were not registered could be transferred only after they were surveyed and the title clearly established.

Severe penalties were prescribed for nonpayment of taxes, evasion, or false reports to the tax authorities. If an owner defaulted for 3 consecutive years, the government could obtain a court order to seize the land, sell the harvest, and collect from the proceeds.

${ }^{5}$ M.M.S. Farhang, Afghanistan in the Last Five Centuries (title translated from the Dari), 1988, p. 531. 
A land reform law was also passed. Promulgated in 1975 and effective July 1976, this law prescribed ceilings on landholding and set up procedures to transfer excess land to poor and landless farmers. The ceilings varied with the quality of land and were as follows:

$\begin{array}{lr}\text { Grade and type } & \text { Ceiling amount } \\ \text { First } & \\ \text { Double cropped irrigated } & 20 \\ \text { Orchards } & 20 \\ \text { Second } & 30 \\ \quad \text { Single cropped irrigated } & 40 \\ \text { Third } & \\ \text { Dry farmed } & \end{array}$

The land in excess of the ceilings was to be distributed in lieu of payment to landless farmers over 25 years, with an interest rate of 2 percent a year. A priority list was created for distributing the surplus land as follows:

1. Farmers who, before promulgation of the law, had been engaged in farming the land to be distributed;

2. Landless and small farmers in the same village as the land to be distributed;

3. Graduates of agricultural and veterinary schools in the same region;

4. Landless nomads; and

5. Landless farmers and agricultural and veterinary graduates from other regions.

An administrative system complete with special courts was set up to enforce the new law.

In contrast to the terms for those who would lose land, beneficiaries would pay for the land in annual installments at an interest rate of 3 percent. They would receive temporary title documents but would not be able to sell the land until after they had paid for it and met their other legal obligations, that is, tax obligations. Beneficiaries were not allowed to subdivide their plots.

Because the land ceilings were relatively high, and because of provisions that permitted landowners to dispose of their excess land within 2 years, little land was available for distribution. The government was also aware of its administrative limitations and intended to implement the law gradually over a 10-year period. In the meantime, priority was given to the extension of the cadastral survey and implementation of the land tax law. 
The law on survey, settlement, and registration of lands that became effective September 1978 provided ways to use the information from tax declarations and land surveys. These tax declarations and land survey records issued by the cadastral survey were to be used by the settlement commission to determine ownership and tax obligations. The titles were to be registered and certifications issued to landowners.

\section{Land Reform}

In December 1978, the Kabul Government issued Decree No. 8 with the objective of equalizing land ownership and broadening its own political base. The decree set a ceiling of 6 ha. on first grade land. The surplus was to be confiscated without compensation to the owners and given to landless farmers and nomads. An absolute ban was imposed on transfer of any surplus land. This surplus was eventually to be distributed in 1-ha. plots. A complicated system was devised to permit the adjustment of the size of plots to ensure that they were of equivalent quality. Beneficiaries received the land free, but were expected to register their titles and pay their land tax and any debts due to the banks.

A total of 100,000 ha. -14 large plantations and 76 palaces and houses were confiscated from the royal family, and the formerly royal land was added to the excess above land ceilings that had been confiscated from private owners as land for distribution.

According to official documents, during the first phase of the implementation of this law, about 296,000 families received 666,000 ha. of land, in addition to 40,000 ha. of land that was transferred to state farms.

However, it appears that very little land was actually distributed because of the weakness of the Kabul Government as well as the confused state of land tenure. An official survey in 1983 revealed that 51 percent of the proposed beneficiaries of land reform received no land-either because none had been distributed to them or they had no capital to undertake its cultivation (Novotny, p. 253). In addition, many farmers refused the allotted land, either because of fear of the former landlords' power or because they believed the reform was immoral.

The 1978 decree was amended in 1983. Tribal, political, and military leaders who sided with the Kabul regime were either given back their land or paid an attractive price for it. New regulations on water resource management were enacted. A further attempt was made to create a central land title registry. Limitations on leasing and subdivision were enacted, but these rules as well have not been enforced. 
From 1987 to the present, effective control by the Kabul regime has declined further. Abandoned lands have been occupied by the mujahidiin and by the limited number of returning refugees. Large-scale private encroachment on public lands has occurred.

In early 1975, the government prepared a new draft water code with assistance from the United Nations Development Programme (UNDP). The new code was amended and enacted by the new regime in 1981. However, the law was not implemented primarily because extensive studies would have been required that the government was in no position to undertake.

Land tax and survey laws were also amended by the new government but have not been implemented. The government has announced its intention to issue new title documents to all of the country's 1.2 million landowners.

\section{Geographic Distribution of Particular Types of Ownership}

In the rural north most of the arable land was privately owned before 1978. In the south, especially in Pashtun, large areas of land were communally owned.

The patterns of tenancy on private lands differ. Although the 1963 survey (Ministry of Planning 1964) indicated that 60.5 percent of land was owner-operated versus 19.3 percent sharecropped and mortgaged (which is a form of lease in Afghanistan) and that the remainder was in other forms of tenure, the percentage of owner-operated land varied from more than 90 percent in Paktia to less than 20 percent in Girishk, where 70 percent was held in some peculiar form of tenure. Nangarhar had the next lowest percentage of owner-operated land with 45 percent owner occupied without mortgage and 44 percent with mortgage. All other provinces had owneroperated percentages of between 50 and 80 percent.

According to the SCA survey of 1988, there has been a relative increase in sharecropping and decrease in owner operation since 1978-1979. The decrease in owner operation is fairly uniform, but the increase in sharecropping is most notable in the northeast and southeast-the areas from which large numbers of refugees have fled.

Table 4 shows the changes by regions. The percentage decrease in owner-operated land was fairly equal among regions, but the increase in sharecropping varied enormously and even decreased in the northwest (see Map 4). The precise factors involved are hard to identify, but among several possibilities are (1) the seizure of land by mujahidiin commanders, (2) displacement of owner-operators within the country as they fled to safer areas to be sharecroppers, or (3) the lack of capital that would permit owner operators to cultivate land to which they have title. 
The largest increase in abandoned farms occurred in the southeastern and east central provinces where most infrastructural damage had occurred. In the northern region, the number of abandoned farms increased by 260 percent. There are suggestions that the landlords' large-scale abandonment of their holdings may have enabled greater success with government land reform efforts. In other areas where land was abandoned and infrastructure remained, the Kabul regime simply moved people in. Despite the resettlement of new tenants in the north, the area under wheat cultivation declined because of the abandonment that did occur. 


\section{Table 4. Land Tenure Survey Responses by Region}

\begin{tabular}{|c|c|c|c|}
\hline Change & $\begin{array}{l}1978 \\
1979\end{array}$ & $\begin{array}{l}1987- \\
1988\end{array}$ & Percentage \\
\hline \multicolumn{4}{|l|}{ Regional averages } \\
\hline \multicolumn{4}{|l|}{ Northeast } \\
\hline $\begin{array}{l}\text { Owner-occupiers } \\
\text { Sharecroppers } \\
\text { Abandoned farms }\end{array}$ & $\begin{array}{r}75 \\
24 \\
4\end{array}$ & $\begin{array}{l}46 \\
38 \\
11\end{array}$ & $\begin{array}{r}-38.7 \\
58.3 \\
175.0\end{array}$ \\
\hline \multicolumn{4}{|l|}{ North } \\
\hline Owner-occupiers & $\begin{array}{l}78 \\
22 \\
7\end{array}$ & $\begin{array}{l}56 \\
25 \\
25\end{array}$ & $\begin{array}{r}-28.0 \\
13.6\end{array}$ \\
\hline \multicolumn{4}{|l|}{ Southeast } \\
\hline Owner-occupiers & 94 & 61 & -35.0 \\
\hline Sharecroppers & 11 & 26 & 136.0 \\
\hline Abandoned farms & 5 & 29 & 480.0 \\
\hline \multicolumn{4}{|l|}{ East Central } \\
\hline Owner-occupiers & 84 & 67 & -20.0 \\
\hline Sharecroppers & 18 & 23 & 28.0 \\
\hline Abandoned farms & 4 & 27 & 575.0 \\
\hline \multicolumn{4}{|l|}{ Southwest } \\
\hline Owner-occupiers & 89 & 46 & -48.3 \\
\hline Sharecroppers & 18 & 18 & 0 \\
\hline Abandoned farms & 13 & 51 & 292.0 \\
\hline \multicolumn{4}{|l|}{ Northwest } \\
\hline Owner-occupiers & 54 & 35 & -35.0 \\
\hline Sharecroppers & 38 & 32 & -16.0 \\
\hline Abandoned farms & 12 & 41 & 241.0 \\
\hline \multicolumn{4}{|l|}{ National averages } \\
\hline Owner-occupiers & 80 & 56 & -30.0 \\
\hline Sharecroppers & 21 & 26 & 24.0 \\
\hline Abandoned farms & 7 & 31 & 342.0 \\
\hline
\end{tabular}

Notes: Differences in percentage changes between this table and the source are due to rounding.

Source: Swedish Committee on Afghanistan, The Agricultural Survey of Afghanistan, First Report, Annex 2, Table 4, May 1988. 


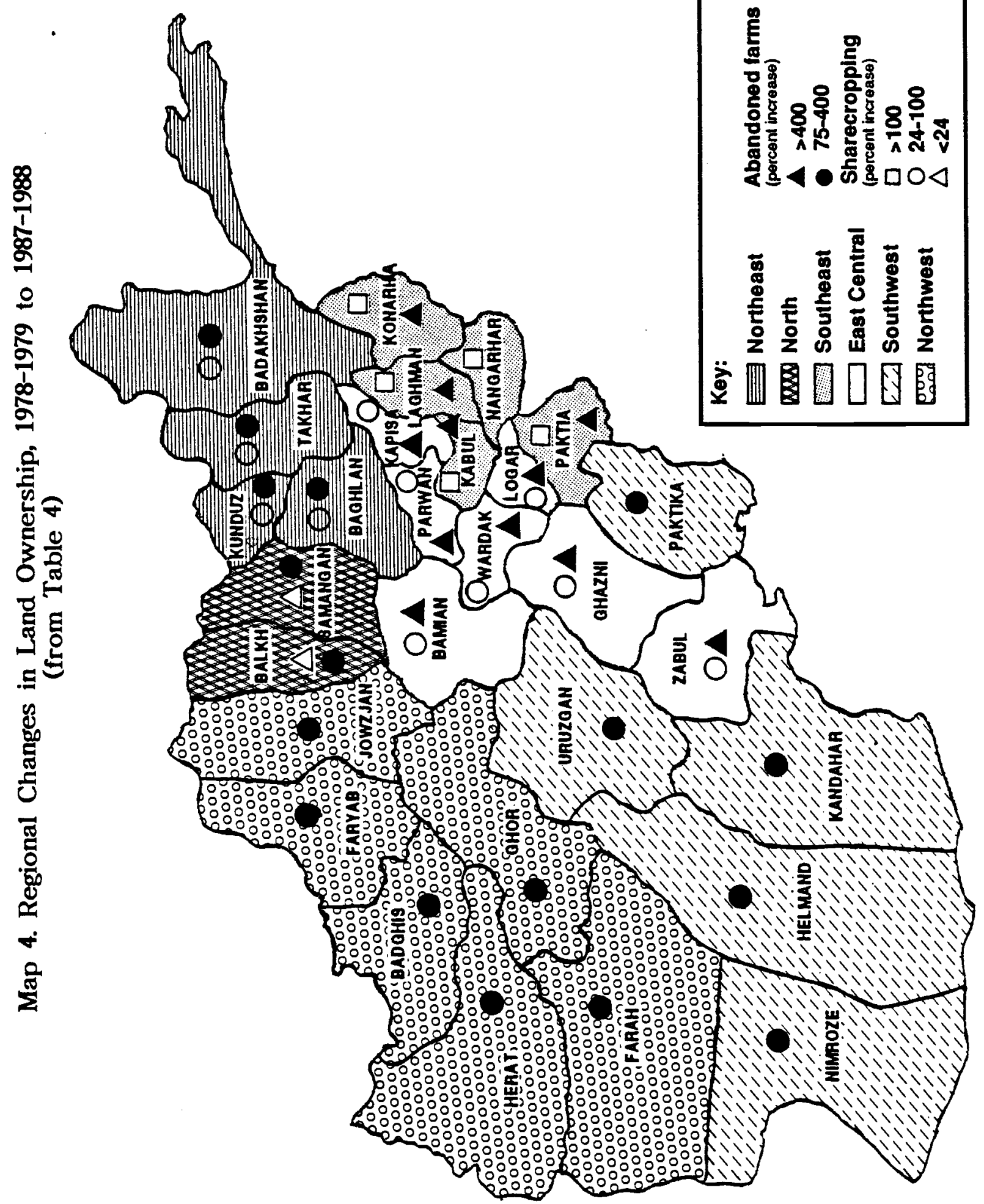




\title{
3 \\ LAW AND CUSTOMARY REGULATIONS ON STATE-OWNED, COMMUNAL, AND COMMON LANDS
}

\author{
Historical Background
}

According to sharia, lands neither privately owned nor cultivated belong to the state. In theory, the state owned three categories of rural land. First, Waqf Muslim religious trust land had been nationalized in the 1890 s by Abdur Rahman. Second, the floodplain that borders the south shore of the Oxus River (Amu Darya) from Samangan upstream was government land in principle but was used in practice by local residents for private purposes. Finally, the government claimed all wasteland, forests, and pastures but made little attempt to restrict or regulate productive initiatives on it. The state also had various claims to categories of arable land. In principle, any land that carried no valid private title came under state ownership, in practice much was held in communal tenure.

Pasture land was used by approximately 1.5 million nomads and an uncertain number of sedentary livestock owners and their families. Eighty percent of the total livestock was owned by the nomads. Violent conflicts sometimes occurred between nomadic and sedentary livestock owners (especially in the Hazarajat area) that sometimes led to government intervention.

Over the last century, thousands of acres of public land in the northern provinces had been distributed to people from the south and east-partly as a strategy to encourage Pashtuns to settle among the largely Turkic peoples in the north. Some of the government land in irrigation projects (see Map 5 for approximate project locations), such as the Helmand Valley Authority, Nangarhar Canal, Sardeh, and Parwan, was also distributed with similar intent. From 1973 to 1977 more than 17,000 ha. of land was distributed to 3,500 landless families under these projects. From 1952 to 1978 , more than 10,000 landless persons were given land. Title to the land was to be transferred when they finished paying the government for it. Other government lands, 


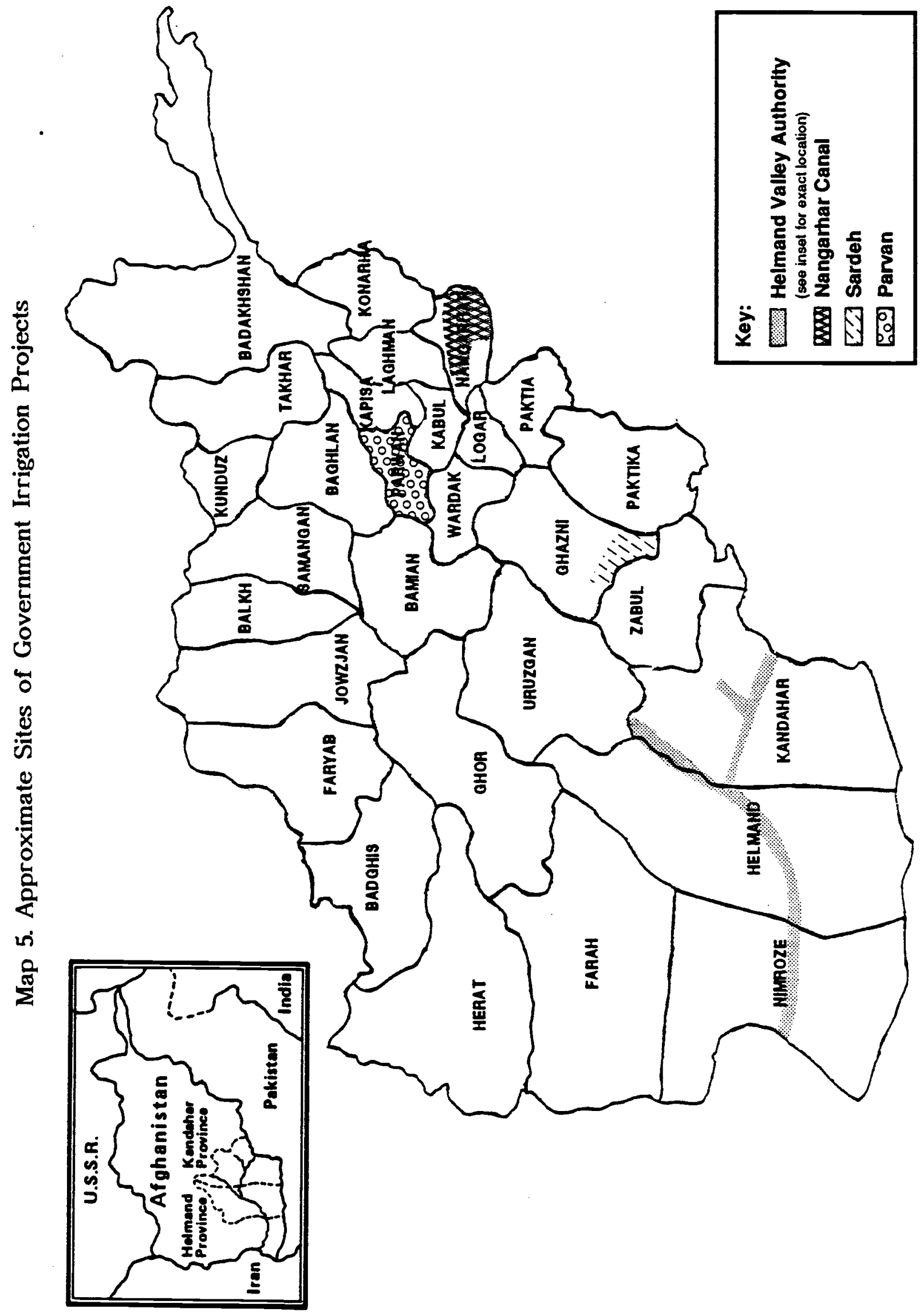


particularly in the north, were leased informally to private individuals on short-term leases, and nonirrigated land, as noted elsewhere in this report, was leased on long-term leases to encourage investment in irrigation. No legal basis for leasing such lands existed.

There were no provisions for public lands in either the 1931 or the 1964 constitutions. The Constitution of 1975 declared natural forests, mines, and pastures state property. This declaration simply confirmed what had generally been assumed and practiced previously. It was hoped that the cadastral survey would define both private and state land rights legislation in forests and pastures.

\section{Adequacy of Environmental Protection on Public and Common Lands}

Of the 1.9 million ha. of forest land reported in 1978, only 1.7 million ha remains according to the Kabul regime's official figures, but the actual amount is probably much less. Utilization of these forests was always inefficient. Sixty percent of the available wood is estimated to be wasted. Primitive logging techniques include the use of crude axes and burning of trees.

The forests were already being destroyed and the land they protected eroded before the 1978 coup. The problems were exacerbated by the propinquity to Pakistan, which was the destination for massive timber smuggling. Two areas with government-sponsored programs were an exception: Mandahair in Paktia with German technical assistance and Dehwaigal in Kunar with UNDP/FAO assistance. Even these forests have now been mostly cut down.

The current rate of deforestation is unknown. Official Kabul Government estimates place it at 10 to 20,000 ha./year. Before 1978 , the rate of felling was estimated at about 1 million $\mathrm{cm}^{3} /$ year, substantially above the annual growth rate. The rate of logging has accelerated in recent years because of increased economic pressure on rural residents and lessened government control over rural areas.

Past rules and practices pertaining to the management of forests, grazing lands, and agricultural land and water resources were inadequate. The rate of timber extraction was excessive and unsustainable. The situation has been exacerbated since the beginning of the war. If no action is taken, the Kunar and Paktia forests will be completely destroyed in the next 3 to 4 years-imposing high social costs such as unemployment, erosion, and worsening climate. The situation is better in the pistachio forests and production has been sustained. Because these forests have been the source of livelihood for a large number of people, an alternative source of employment will have to be developed for them. 
As far as the roughly 40 million ha. of pasture is concerned, grazing was uncontrolled and beyond the carrying capacity of the land, particularly in areas close to water sources and during droughts, which occurred on average once every 2 to 4 years.

Transhumants and nomads have used the same migratory routes for hundreds of years. Certain areas are already overgrazed, especially the winter camping areas (Dupree 1980, p. 179). The expansion of cultivated areas over time has led to a decline in available pasture. There is no legislation regulating these areas.

Protection for forest and pasture land has always been inadequate, and the situation is even worse today, partly because of uncertainty about tenure. If communal tenure was more clearly defined, the communities as a whole might take better care of these lands. Other measures are required as well to create incentives for protection and to facilitate the technologies to use pastures and forests on a sustainable basis.

The amount of publicly owned arable land is relatively small. Private arable land poses the normal environmental protection problems of private cultivation: overextraction of nutrients and underfertilization, overtillage with insufficient attention to restoring soil structure, and waterlogging and salinity from improper drainage (especially in the Helmand Valley). These conditions are all exacerbated by general deforestation and the removal of protective shelter belts. All require attention as part of agricultural development, but could be handled within a secure system of private land tenure.

The actual status of forests, pastures, and arable land is uncertain, although the forthcoming studies on the environment and water resources by Nathan Associates and Louis Berger International should provide a better sense of the situation. USAID's ability to take action in the area is limited. Although some proposed activities will require clarification of land and water control rights-reforestation, rehabilitation of irrigation facilities, and so forth-investors will be reluctant to participate and administrators will be less capable of managing these activities unless the tenure situation is clarified.

Once the limits of public lands are determined, programs for reforestation and controlled exploitation can be initiated, encroachment on pasture land by cultivators can be prevented, and soil conservation measures can be undertaken. 


\title{
4 \\ LAND TENURE PROBLEMS ANTICIPATED WITH THE RETURN OF REFUGEES
}

\author{
Major Resettlement Issues
}

Afghan refugees, when asked to assign a priority to their anticipated problems upon return to their country, generally fail to list land tenure as a source of concern. Not surprisingly, food, shelter, medicine, and education are typically mentioned but not land tenure, even though land is the most important resource.

When asked about the possibility of land tenure problems, refugees respond that "everyone in Afghanistan knows what land belongs to whom." This response is so common that it engenders a growing confidence until it recognized that this is the same rhetorical tone that accompanies claims that "everything will be fine once Afghanistan has an Islamic government." Consequently, it may be that we are facing a psychocultural form of denial, or a feeling that this is a matter in which foreigners, even friendly ones, are not welcome to intrude.

The potential for land tenure difficulties is immense, and when they emerge, it would be useful to prepare some of the infrastructure, institutional, and legal arrangements to meet them. Such arrangements are discussed in Chapter 5.

The difficulties to be addressed will depend to a considerable extent on the existing political scenario. If resettlement includes some participation by the present Kabul regime, consideration will have to be given to the status of land reform and the redistribution it has pursued. If the countryside is dominated, as seems likely, by mujahidiin commanders, the status of the land redistributions and changes in tenure conditions that they have undertaken a piecemeal will have to be addressed. 
The problems will be exacerbated by Afghanistan's ethnic heterogeneity. In Kunduz and other parts of the north, for example, Pashtuns have left their agricultural land, much of it acquired with government sponsorship over the last century, in greater proportions than the older settled, non-Pashtun groups. Some of these other groups, especially the Uzbeks, have long regarded many of these Pashtun holdings as illegal and inequitable. Anecdotal reports have reached Peshawar of land around Khanabad that has already been confiscated by mujahidin commanders, even in instances in which the Pashtuns have cooperated with the jihad. In Hazarajat, in the center of the country, the Hazaras asserted their authority early in the war and denied Pashtun nomads the grazing rights that had been granted by Abdur Rahman Khan a century ago. A senior Afghan NGO official in Peshawar, himself a Pashtun, reports repeated Pashtun and Hazara clashes in Uruzgan.

Irrigation-its extent and state of deterioration-is likely to exacerbate the land tenure controversy. The patterns of land use may have to be altered, radically revaluing traditional land rights and creating potential causes for conflict. Those who formerly had valuable land may discover that their land has lost its fertility and may try to apply to the tribal community to reallocate land in their favor.

Increased mortality as a result of more than a decade of war will also exacerbate land disputes. The large numbers of widows with young children and no adult male kinsmen, although guaranteed land by the sharia may have difficulty enforcing their rights.

The lack of security in Afghanistan since 1978 has had a devastating effect on the country's social and economic development. Of Afghanistan's 17.15 million people, 4.6 million live outside the country as refugees, primarily in Pakistan and Iran. Almost 80 percent of the refugees come from within 200 $\mathrm{km}$ of the border. Almost 50 percent of the refugees in Pakistan come from four provinces: Nangarhar, Kunar, Paktia, and Kandahar. About one-fifth come from the northern and northeastern provinces, and nearly one-sixth are from Kabul and the adjoining provinces. According to the United Nations Research Institute for Social Development (UNRISD) survey in Pakistan, nearly 70 percent of refugees are Pashtuns. In addition, there are several million internal refugees, who have moved from one region of the country to another.

The return of more than 4 to 5 million people after 12 years of exile will put heavy pressure on the country's already shattered rural economy. So far very few refugees have returned, but the circumstances under which they will return are unclear.

Over the last 12 years, Afghanistan's GDP dropped by 23 to 25 percent, and food production declined by 30 percent; the country's population has dropped by far less. Considerable infrastructure in an already poorly equipped country has been destroyed. In some areas the destruction has been more severe than in others. In the north, only Kunduz has been severely 
affected, whereas the eastern and southeastern regions have both been severely affected.

Vast expanses of cultivated land have been abandoned. According to a survey conducted by the Swedish Committee on Afghanistan in 1988, the number of abandoned farms increased threefold between 1978-1979 and 19871988 (see Table 4).

Many of the abandoned farms were owned by relatively large landowners who are now refugees. The average amount of land that had been owned by refugee farmers is 47 percent larger than the average holding of farmers who remained in Afghanistan.

Although the poorer farmers rejected land reform, they have cultivated the abandoned land for the last 12 years. During this period, the average number of owners decreased by 30 percent whereas the number of sharecroppers and "caretakers" increased by 24 and 176 percent, respectively. Repossession of land that has been cultivated by such caretakers could provoke serious conflicts.

In addition, it is believed that there has been a frantic scramble for land during the last 2 years. Some of the thousand-odd mujahidiin commanders have seized lands either for themselves or to distribute to their followers. In some areas, especially Nangarhar and Kunar, the mujahidiin leased lands to tenants on much better terms than did the previous landlords. The new tenants may resist any attempts to return such lands to the old tenurial conditions. In other areas, tenants simply stopped paying rents and tried to establish title to lands. In some areas small farmers have expanded their plots at the expense of neighbors who are now refugees.

Efforts to resolve these matters will be complicated by the lack of a land registration system and unclear land titles.

Traditionally, conflicts about land or water rights would have been resolved by jirgas or councils of village elders. The village headman or malik or arbab served as a link between the village and the government as well as the large absentee landlords. This system was characteristic of all ethnic groups. The turmoil since 1978 has undermined many of these traditional mechanisms, and the leading figures, to the extent they have been in exile, may have difficulty recovering their position. Currently no effective central authority exists in the country, and there are many competing local authorities.

USAID must return to the first principle of land rights in agrarian societies - that they reflect local power structures and consensus. A new structure that is different from the one in 1978 and the one that is in place now will exist after an Afghan political settlement. In the immediate 
resettlement period, reliance on local community organs will likely be the only possible means for dealing with the land problem.

The most serious difficulties will emerge when no one community has clear jurisdiction, a situation likely to occur when two ethnic groups, such as Pasthun nomads and Hazaras in the Hazarajat, confront each other. Even here the solution is likely to lie in recognizing the two communities and bringing them to the bargaining table rather than imposing a central solution. At the extreme, of course, no central government can permit civil war, and it is in this connection that the government will have to consider the relevant rules and precedents and act accordingly.

Resolving the land rights problem in the resettlement period will be a particularly sensitive task for a new Afghan government because the tradition has been for the state to ignore or deny its ethnic heterogeneity. Many of the leading forces among the mujahidiin and in Kabul as well come from nonPashtun or non-elite Pashtun backgrounds and are apprehensive that their new-found positions may be undercut in a new free Afghanistan.

\section{Implications for Returning Refugees}

The issues discussed in the preceding paragraphs have serious implications for the capability of returning refuges to support themselves. Income and poverty are linked in several studies with irrigated land per capita. Historically, in Nangarhar per capita irrigated land was 0.2 ha. and 60 percent of the rural population was in absolute poverty. By contrast, the percentage of landholding in Baghlan was 0.48 ha. and only 11 percent of the rural population was in absolute poverty. Even before 1978, 30 to 50 percent of the rural population in Afghanistan was in absolute poverty, and the situation has declined in recent years (see Tables 5 and 6).

Table 5. Average Annual per Capita Income and Land Availability of Selected Provinces, 1970

\begin{tabular}{lcccc}
\hline Province & $\begin{array}{c}\text { Sample } \\
\text { Population }\end{array}$ & $\begin{array}{c}\text { Average } \\
\text { Income per } \\
\text { Capita (Af) }\end{array}$ & $\begin{array}{c}\text { Average Irrigated } \\
\text { Land Equivalent per } \\
\text { Capita (jeribs) }^{\mathbf{a}}\end{array}$ & $\begin{array}{c}\text { Percentage of } \\
\text { Population in } \\
\text { Absolute Poverty }\end{array}$ \\
\hline Baghlan & 1,015 & 6,670 & 2.40 & 11 \\
Kandahar & 990 & 5,631 & 2.40 & 25 \\
Kunduz & 1,125 & 4,508 & 2.54 & 21 \\
Parwan & 684 & 2,653 & 0.92 & 48 \\
Ghazni & 1,633 & 2,514 & 1.07 & 59 \\
Nangarhar & 1,094 & 2,041 & 0.93 & 60 \\
Laghman & 385 & 2,671 & 1.28 & 47 \\
\hline
\end{tabular}

${ }^{a}$ Three jeribs of dry farmed land are assumed to equal one irrigated jerib. (Five jeribs equal one hectare.)

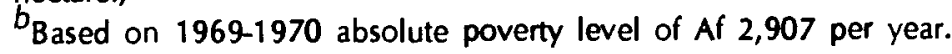

Source: Ministry of Planning, Survey of Progress, 1970-1971. 
Table 6. Agricultural Population and Land Ownership of Selected Provinces, 1977-1978

\begin{tabular}{|c|c|c|c|c|c|}
\hline & $\begin{array}{l}\text { Agricultural } \\
\text { Population }^{a}\end{array}$ & $\begin{array}{l}\text { Area Cultivated } \\
\text { (hectare) }\end{array}$ & $\begin{array}{l}\text { Land/Man } \\
\text { Ratio }\end{array}$ & $\begin{array}{l}\text { Number of } \\
\text { Landowners }\end{array}$ & $\begin{array}{l}\text { Average Size of } \\
\text { Holding (ha.) }\end{array}$ \\
\hline \multicolumn{6}{|l|}{ Selected provinces } \\
\hline Kabul & 365,794 & 65,528 & 0.18 & 35,430 & 1.85 \\
\hline Logar & 191,191 & 62,017 & 0.32 & 24,840 & 2.50 \\
\hline Nangarhar & 620,684 & 59,785 & 0.10 & 87,760 & 0.68 \\
\hline Paktia & 425,331 & 66,600 & 0.16 & 60,761 & 1.09 \\
\hline Paktika & 219,456 & 46,600 & 0.21 & 31,285 & 1.48 \\
\hline Konarha & 223,231 & 25,602 & 0.11 & 25,700 & 1.00 \\
\hline Kunduz & 403,443 & 286,072 & 0.70 & 32,050 & 8.92 \\
\hline Baghlan & 377,813 & 222,616 & 0.58 & 32,540 & 6.84 \\
\hline Kandahar & 349,889 & 152,549 & 0.44 & 48,430 & 3.15 \\
\hline Helmand & 441,890 & 157,852 & 0.36 & 27,450 & 5.75 \\
\hline Herat & 514,257 & 326,471 & 0.63 & 68,150 & 4.79 \\
\hline Ghazni & 554,547 & 155,200 & 0.28 & 53,184 & 2.91 \\
\hline Subtotal & $4,687,526$ & $1,626,892$ & 0.35 & 527,580 & 3.08 \\
\hline Other provinces & $5,294,828$ & $2,250,741$ & 0.48 & 658,530 & 3.83 \\
\hline Total & $9,982,354$ & $4,147,633$ & 0.40 & $1,186,110$ & 3.50 \\
\hline
\end{tabular}

${ }^{a}$ Rural population was adjusted by 10 percent to produce these figures. Data on rural population are presented in Macroeconomic Database Development, Nathan Associates, Appendices, January 1990, Tables A VI-5 and A VI-6.

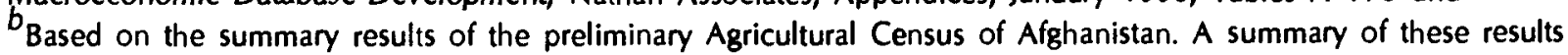
is presented in Afghanistan: Current Economic Situation, World Bank, 1971.

$C_{\text {It }}$ is assumed that the land ownership pattern given by the agricultural census has remained unchanged until 1978.

The return of 4 million cross-border refugees will obviously increase population density and consequently upset the economic balance in some areas. The return of internal refugees will further exacerbate the situation. Many of the refugees have been dependent on international relief organizations for several years and will have to become reaccustomed to earning a living. Only 18 percent of the refugees in Pakistan have been gainfully employed and many of those that are employed work in low-paying jobs on an irregular basis. Their households are normally large; the average size of a household in the refugee camps is 8.5 dependents as opposed to a pre-war average of 7. Population has also increased despite the casualties in the war years, putting additional pressure on the land.

The majority of returnees will be sharecroppers or subsistence farmers in rural areas who will benefit little from conventional, commercially oriented production programs. Under current market conditions, farmers with less than 2 ha. of land will be unable to diversify out of subsistence into high-value commercial cash crops. 
As a result of these constraints, some smaller farmers in Helmand (primarily), Badakhshan, Kunar, and Nangarhar had begun to cultivate poppy even before the war. Best estimates are that before 1978, 200 to 400 tons of opium and 500 tons of cannabis were grown annually in Afghanistan. Prices are reported to be rising, and cultivation is expanding. ${ }^{6}$

Since the war, because of limited government power and economic pressure, opium production has expanded rapidly in Helmand, Badakhshan, Kunar, and Nangarhar as well as in parts of the Herat area. USAID and the United Nations Fund for Drug Abuse Control (UNFDAC) have been supporting anti-opium campaigns.

Agricultural production, never very high, has declined during the years since 1978. Restoring it will require investment, particularly in irrigation, which will be more difficult to mobilize without regularizing the tenurial situation. This is not to imply that much cannot be done with the irrigation system before tenure is regularized.

Resettlement problems will differ among three classes of returnees: landless sharecroppers, small subsistence farmers who own their own land, and larger landlords. Landless sharecroppers will be in much the same situation they were in before the war, but it will be exacerbated by years of enforced idleness, increased population density, and greater competition for employment.

Small farmers will have to deal with squatters on their lands, including those placed there by local mujahidiin commanders, the decline of the irrigation systems on which they depended, uncertainty of titles, and the settlement of many old liens and debts.

Larger landlords will have to recover some of their lands from those who have seized them either under land reform legislation or on the orders of mujahidiin commanders. They will also be faced with the problem of recovering their debts and persuading tenants and sharecroppers to return to their service or they will have to recruit new laborers. Many landlord families will be helped by the fact that they have left family members in place to watch their lands and crops.

\section{Issues and Principles To Address Confiscated Lands Issues}

As indicated earlier, a considerable amount of land has been seized, either by the Kabul regime in connection with the 1978 land reform or by mujahidiin commanders who have informally assigned it to their followers.

${ }^{6}$ The Economist, July 6, 1991, 34-35. 
When a national political authority is established it will have to give priority attention to these issues. Some general legislation will be required; however, it will be necessary to rely to a considerable degree on local institutions to handle the matters on a case-by-case basis.

The first issue to resolve, which will depend on the precise form the new government takes, is whether it will retain the 1978 Decree No. 8 as modified in 1981, return to the 1975 Daoud era land reform law, or return to the period before 1975 when there were no land ceilings. In any case, the new government eventually needs to continue the cadastral survey begun in 1978. It will be necessary for the new government to respond more than did the previous government to local community demand and to rely on local consensus as well as land tax records to establish land rights. Only the local consensus reflects legitimate and enforceable rights-especially so in the likely postwar situation of a weakened central government.

\section{Relationship Between Land and Water Rights}

According to Dupree (1980, p. 148), "agricultural production in Afghanistan involves five elements: land, water, seed, animal or mechanical power, and human labor. Theoretically, whoever contributes one of the elements receives one-fifth of the crop. Land and water rights go together."Although Dupree's model may not be followed in practice, it represents one conceptualization of the rights to the land's produce.

Water rights are as important as land rights in rural areas. Although karezs and wells are often privately owned, canals are typically owned and maintained by the community or sometimes individuals.

Water from canals is allocated according to farm size and historical rights by numbers of hours or days per week. Allocation is typically biased in favor of large landholders. Upstream users tend to overuse and waste water, so less is available for those farther downstream. The system is not adjusted to cultivation needs.

In many systems water is allocated by a mirab or watermaster selected by the farmers, who manages the system. Theoretically, the watermaster is supposed to protect everyone's rights but is usually heavily influenced by the larger and upstream users. Efficiency is typically low, and in some systems an estimated 30 percent of the available water is wasted before it gets to the user. The war has further destroyed many irrigation systems, and the irrigated area has declined by about 20 percent. There is no question that water scarcity will exacerbate the pressure of population in resettled rural areas.

In view of this problem, the resolution of water rights should receive priority attention. Fortunately, considerable progress has been made over the 
last two decades on how to resolve the issue of water rights based on experience in other countries in South Asia and documented in the work of Rabert Chambers. Nevertheless efforts will have to be made to reorient government and local officials on the basis of Chambers' work.

As an interim measure there is a need to recognize the traditional irrigation arrangements and the role of the mirab, with all of its faults, and indicate that any water disputes should be referred to the village council for resolution. Priority needs to be given to rehabilitating the established water systems and their traditional managements. 


\section{5 \\ OPPORTUNITIES FOR USAID}

USAID might take any one of four approaches in becoming involved in land tenure issues: (1) minimize and resolve land disputes as refugees return; (2) provide incentives for farmers to invest in their land; (3) create a record to facilitate agricultural credit; (4) enhance sharecroppers' security (although probably not at this time) to encourage them to invest in the land, and perhaps pursue social equity.

These approaches represent several possibilities. The first and easiest is to continue the pre-1978 effort to secure a comprehensive registration of land rights, probably combined with a land survey and programs to train Afghans in surveying skills. USAID might also support programs to consolidate scattered plots belonging to one owner; this would help secure the purposes sought by the first three approaches.

A program for regulating and registering sharecropping arrangements would help to a limited extent but would primarily be directed to the last approach-enhancing sharecropper security.

Because substantial problems can be anticipated in connection with land ownership when large-scale resettlement of refugees occurs, USAID might consider several levels of involvement. As far as private lands are concerned, some assistance might be given, on a pilot basis, to an effort to improve the cadastral survey. Even now some pilot surveys might be undertaken, partly with a view to training a cadre of survey workers who might be available either to work in a new governmental cadastral survey or to work as private surveyors, assisting landowners and village communities establishing their records of land rights. This could be undertaken as a free-standing project or it might be done in collaboration with some NGO or local government resettlement project.

Because these activities will have to be conducted locally, they provide the opportunity for experimentation with various combinations and approaches. The Mission might consider explicitly designing its programs on an experimental basis. A certain number of villages could undergo a full survey; in other villages the survey could deal only with private lands, and in 
others, a "rough and ready" registration of titles could be done leaving others untouched.

For the foreseeable future, there is little likelihood that any formal rearrangement of land titles or land reform will occur; some de facto tenancy reform has already been reported. A number of the commanders have reportedly imposed limits on landlords' shares, and a new central Afghan government may seek to do so as well. It might be desirable to combine some of the pilot surveys with the recording of written leases as a means of protecting tenants' and landlords' rights. There is a need to provide some security of tenure to provide incentives for agricultural investment and production.

Further, USAID might use the incentive of agricultural assistance to persuade communities to regularize their land tenure and water usage arrarigements as a precondition for such assistance. Otherwise, it is quite possible that tenurial and water problems will undercut the possibility of agricultural growth. Communities might be required to begin a cadastral survey to document land and water rights.

Elsewhere in the world, the prognosis for tenancy reform is far worse than that for land ceilings. It has generally proved impossible for governments to enforce. The only results of attempts to enforce the recording of leases and regulate the conditions that they may impose in most countries have been to shift land from recorded tenancy, and, in any case, to decrease the security of tenant rights-demonstrated most authoritatively by Herring (1983). The situation in Afghanistan may differ because a redistribution of land title is absolutely rejected as "un-Islamic" at the same time that "fair price" regulations under Islamic law are approved. The power of landlords has been considerably reduced, particularly after they migrated; political control now lies with non-landlord mujahidiin commanders. While the ideology of Islamic economics forecloses any reform in landownership, at the same time it enables some tenurial reform.

In theory, it might be desirable to move from the current dominance of sharecropping arrangements to fixed-rent leases, giving greater incentive to the tenant to undertake agricultural investment and to the landlord to increase his take by lending money for investment in agriculture. However, experience in other countries suggests that lease arrangements that are used respond to the ease or difficulty of supervision of agriculture and are difficult to manage by decree.

Somewhat easier to manage than tenancy reform is the consolidation of scattered plots, which turns out to be extremely popular in irrigated areas in some countries because it permits the enhancement of production levels. Such consolidation, however, can be accelerated by the development of a land surveyor, who can make the reasonably accurate assessment of land value that is required (Oldenburg 1990, pp. 183-195). 
Public lands are both a more important and more easily addressed subject than are private land rights, at least when a new central government emerges in Kabul. A cadastral survey is essential in order to prevent the incursion of private parties on public lands. Assistance to local groups and shuras might again be predicated on their surveying public lands and using the skills of the newly trained surveyors that were developed by earlier A.I.D. programs.

Arable lands owned by the state, beyond a prudent minimum that needs to be retained for public purposes (roads, extension stations, irrigation lines, schools, etc.), could be distributed to the landless as a way of reducing pressure on the land. Any such distribution will have to be connected, as is usually the case, with support in the form of extension services and credit. It will be easier to manage such extension if the distributed lands are relatively concentrated. Scattered bits of public land can only be effectively distributed by village communities. It is essential that in addition to the state, village communities retain sufficient land for their own public purposes, including in those areas with appropriate settlement patterns (most of Afghanistan) land for the expansion of the village residential area, cemeteries, schools, and so forth. One of the priority tasks will be road reconstruction, and unless public tenures are clear, preserving rights-of-way could be a nightmare.

Forest and pasture land needs to be subjected to some conservation regime. When a central government is established, it can enact protective measures, or simply enforce some of the measures that are on the books. In the interim, even when some central authority is established, the local government and communities that control these lands must be associated with their preservation, presumably on the basis of their own interest in sustained harvesting. Programs of social forestry, based on these principles, are the best and only way to effectively protect forest and pasture land. Local communities should be given technical and financial assistance in undertaking systematic and sustainable management of these resources. 


\section{REFERENCES}

1. Dupree, Louis. Afghanistan. Princeton University Press, Princeton, N.J.,1980.

2. Feder, Gershon and David Feeney, "Land Tenure and Property Rights: Theory and Implications for Development Policy," The World Bank Economic Review V, January 1991, pp. 135-153.

3. Herring, Ronald J. Land to the Tiller: The Political Economy of Agrarian Reform in South Asia. Yale University Press, New Haven, CT., 1983.

4. Oldenburg, Philip. "Land Consolidation as Land Reform, in India," World Development 18, 1990, pp. 183-195.

5. Smith, et. al. Area Handbook for Afghanistan. Washington, D.C., 1973.

6. Survey of the Social and Economic Conditions of Afghan Refugees in Pakistan 4. UNRISD, Geneva, 1988.

7. Warriner, Doreen. Land Reform and Economic Development. London, Oxford University Press, 1962.

8. Survey of Population and Agricultural Characteristics of a Sample of 413 Villages in Afghanistan. Ministry of Planning, January 1964. 


\section{BIBLIOGRAPHY}

Afghanistan Agricultural Sector Review. UNDP/FAO, Rome, 1985.

Afghanistan:Agricultural Credit. Project Assistance Paper. USAID, Kabul, 1977.

Afghanistan:The Eastern Provinces. The Orkand Corporation, October 1988.

Afghanistan: Journey to Economic Development, 1978, Vols. I and II. World Bank, Washington, D.C. 1978.

Afghanistan:The Northern Provinces. The Orkand Corporation, April 1988.

Afzal-ur-Rahman. Economic Doctrines of Islam. Volume II. 1980.

Agricultural Survey of Afghanistan: First Report. Swedish Committee on Afghanistan, Peshawar, May 1988.

Agricultural Survey of Afghanistan, The. Swedish Committee for Afghanistan, 1989/90 Report, Peshawar, 1990

The Agricultural Survey of Afghanistan, Third Report: Crops and Yields. Vol. I. Swedish Committee for Afghanistan, Peshawar, August 1989.

Appraisal of the Third Agricultural Credit Project:Afghanistan. World Bank, Washington, D.C. 1977.

Appraisal of a Second Agricultural Credit Project:Afghanistan. World Bank, Washington, D.C., 1975.

Chamber, R. Managing Canal Irrigation:Analysis and Lesson from South Asia. New York: Cambridge University Prss, 1989.

Dupree, Louis. "A Flawed Vision of Afghanistan's Future," Washington Post, May 21, 1988, p. A-25.

Eighmy, Thomas. Afghanistan's Population: Inside and Out. USAID, Islamabad, May 1990. 
First Seven Year Economic and Social Development Plan. Vol. I. Government of Afghanistan, Kabul, 1975.

First Seven Year Economic ana Social Development Plan (1976-83)

Government of Afghanistan, Kabul, 1976.

Gibbs, M. David. "The Peasant as Counter Revolutionary: The Rural Origin of Afghanistan Insurgence," Studies in Comparative National Development XXI, 1, 1986.

Lakanwal, A. G. Implementationof Democratic Land Reform in the Democratic Republic of Afghanistan. Leipzig, 1980.

Legislation

Land Law, Qanoon Survey Arazi of 1965

Land Reform Law 197

Land Tax Law 1976

Law of Survey, Settlement and Registration of Land 1976

Land Reform Legislation of 1975 as amended

Decree No. 8, Kabul, Dec. 1978.

Amendment to Decree No. 8, Kabul, August 1981

Water Law, 1981.

Majrooh, S. "Afghanistan Prior to the Coup," in Sovietization of Afghanistan, Afghan Information Centre, Peshawar, 1986.

Novotny, M. The Agrarian Reform and Socio-Economic Change. Prague, 1985.

Opportunities for Agricultural and Rural Development:Sector Report, Vols. I and II, World Bank, Washington, D.C., 1975, p. 59.

Paktia Concept: A Summary of Development Programme for the Paktia Province, 1974-81.1974.

Singh, Inderjit. The Great Ascent: The Rural Poor in South Asia. Johns Hopkins University Press, Baltimore, MD., 1990.

Statistical Yearbook (Dari), Central Statistical Office, 1989/90. 
"UNOCA, Salam Mission Report, Badakshan," Afghan Jehad Magazine, Cultural Council of Afghanistan Resistance, January-March, 1990, Vol. 3.

Yusufi, Qasim. "Effects of War on the Agricultural Situation in Afghanistan," Sovietization of Afghanistan. Afghan Information Centre, Peshawar, 1986.

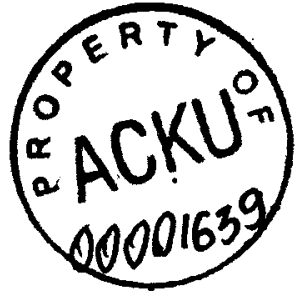

